Historic, Archive Document

Do not assume content reflects current scientific knowledge, policies, or practices. 

111

. .

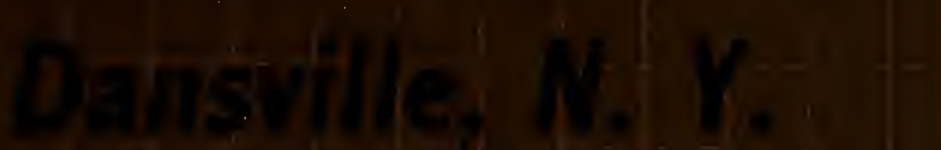

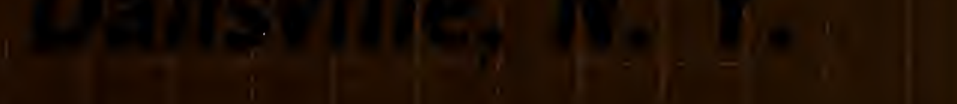

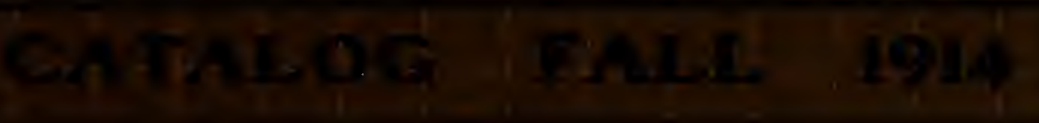

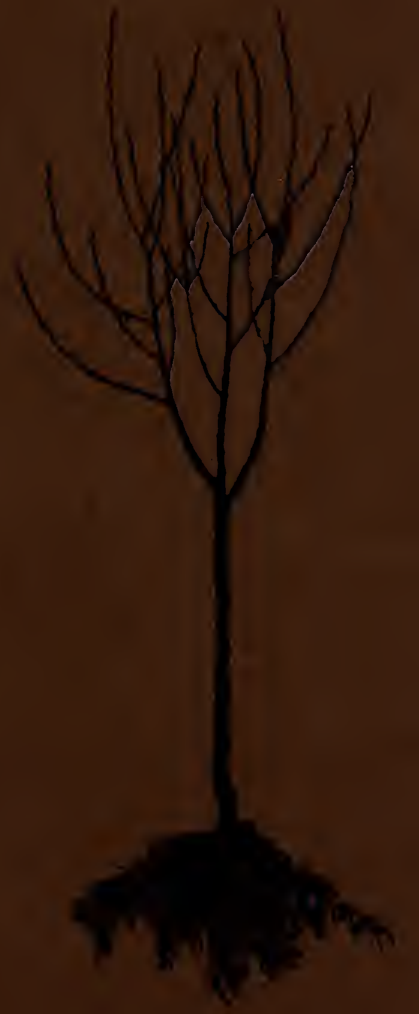

Direct

from

Grower

to

planter

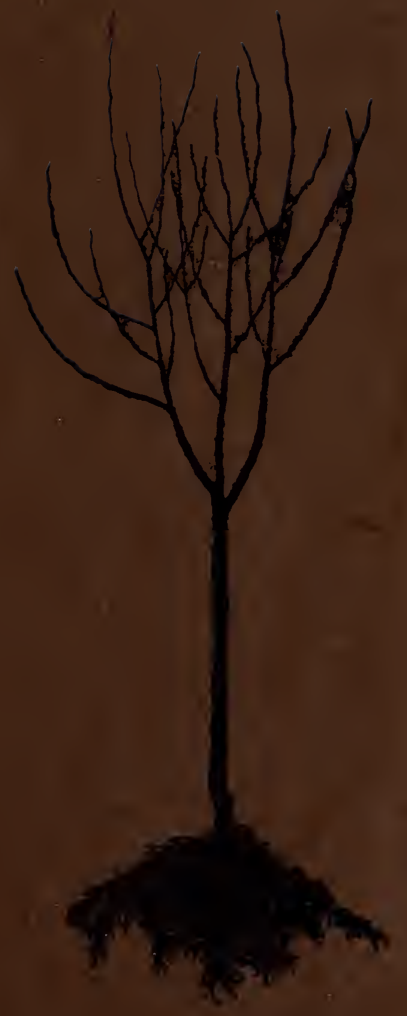




\section{Greetings, Fall of 1914}

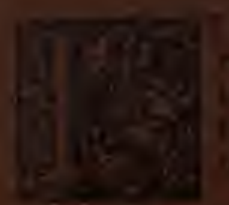

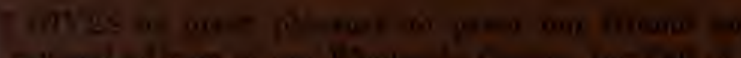

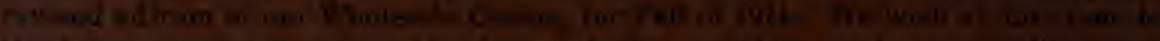

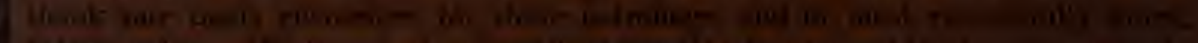

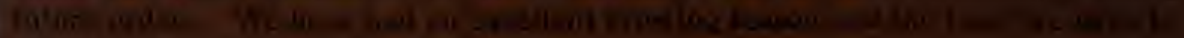

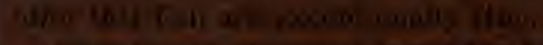

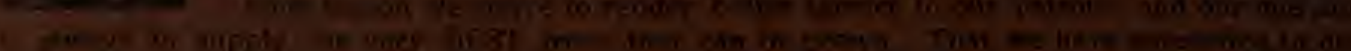

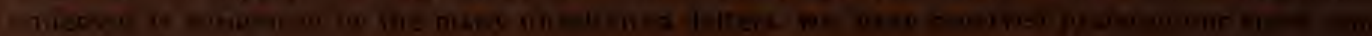

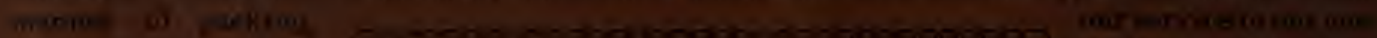

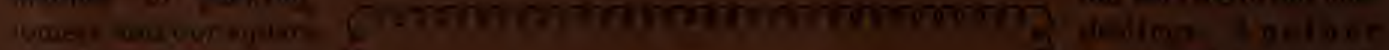

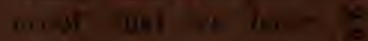

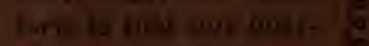

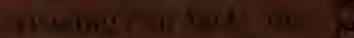

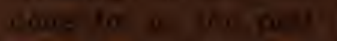

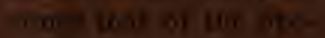

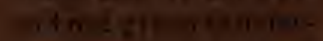

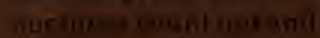

\section{Keli, wamiers DATSVIULES LEADING NURSETOMEN}

9
9
8
3
3
3
3

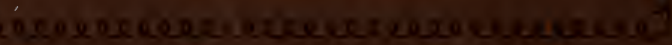

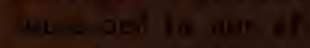
in $10+10$

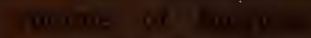
tis nom

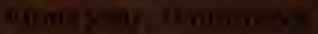
$\operatorname{ling}$ in ate in

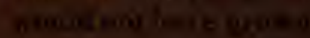

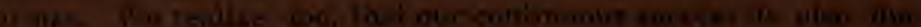

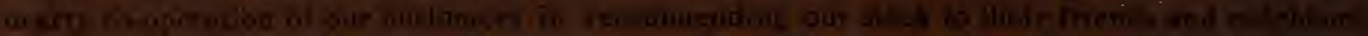

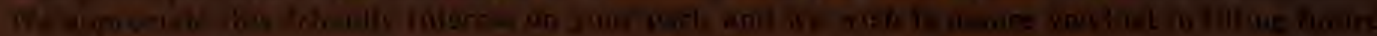

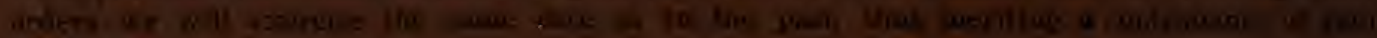
1 Iroliners

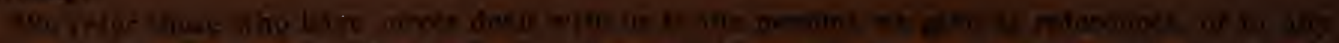

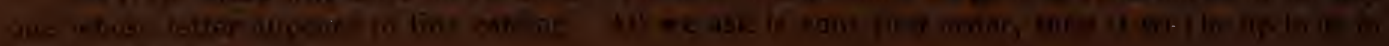
rinto.

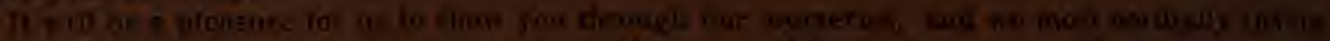

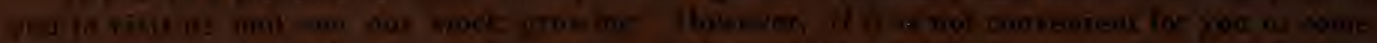

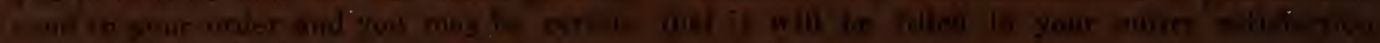

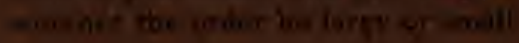

\section{Dos NeJbrences}

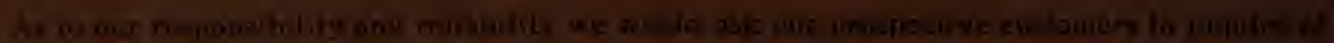

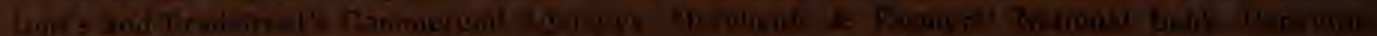

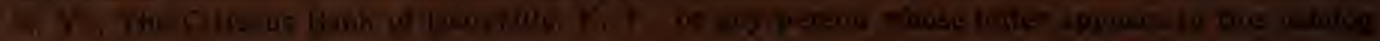

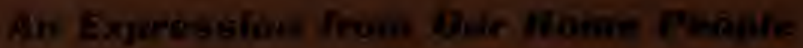

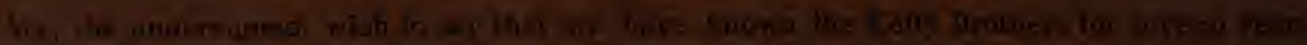

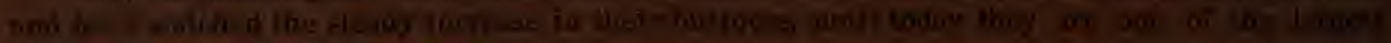

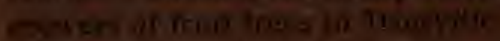

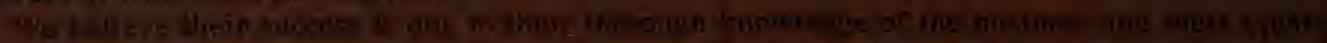

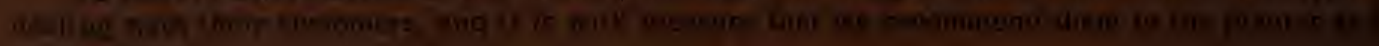
to. 1 know,

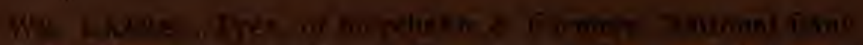

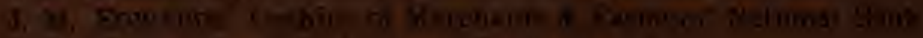

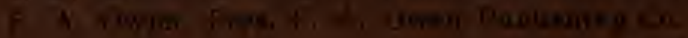

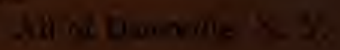

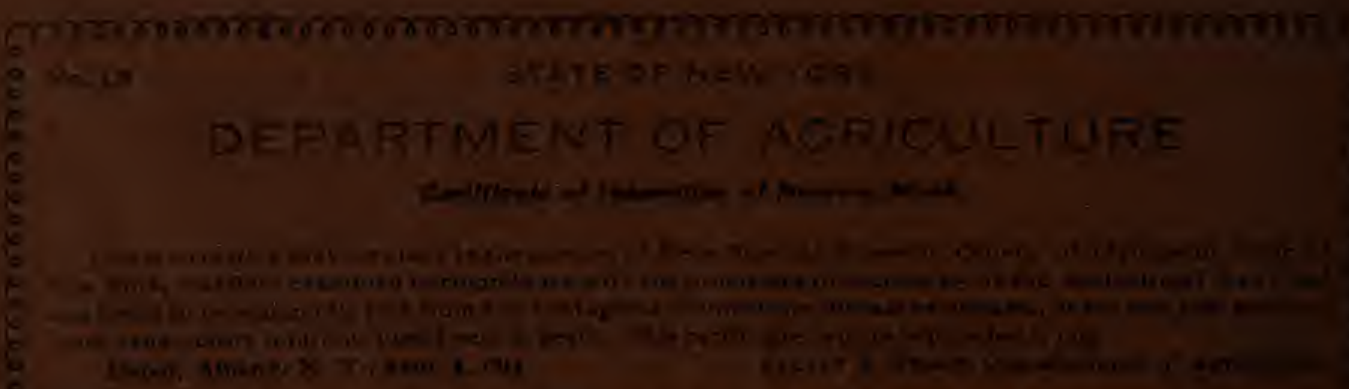

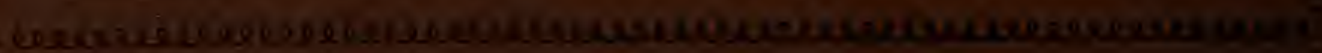




\section{This Catalog is our only Salesman We Employ no Agents}

We could not afford to sell our stock as cheaply as we do if we employed agents whose salaries and commissions often add $50 \%$ to $60 \%$ to the cost of stock. 'This catalog is our only representative anc in buying from it you save the agent's or middleman's large profit. It is not our policy, and we believe it is a waste of your time and ours, for us to explain the methods and practices of some other nurserymen; but we do ask you to not believe the story of the agent who says our trees cannot be first class when we offer them at such low figures. Rather should you be guided by the following taken from the Government Department of Agriculture, Bulletin No. 113:

"If the farmer makes his purchase direct from the nurseryman, he will save the expense of the middleman or agent and is less liable to the mistakes and injuries that may occur through repeated handling."

\section{Established for Twenty-eight Years}

In 1885 we started in the nursery business and each succeeding year our business has steadily grown larger. We began growing fruit trees on a small scale, gradually increasing our plantings until now we have one of the laigest nurseries in the country. In the development of our business our watchword has always been "the best at the lowest possible price." We have always tried to serve our customers so well as to merit their entire confidence and commendation, and we have only to refer to our thousands of satisfied patrons throughout the United States and Canada to prove that we have succeeded in our endeavor. We know that it pays to produce good stock and believe that poor stock, or stock not true to name, is dear at any price-in fact, worthless, even as a gift. We have no agents and for this reason you can buy trees of us at a great saving as the agent's expenses and commission often add from $50 \%$ to $60 \%$ to the cost of stock.

\section{Our Stock}

Our stock is the finest and best that can be grown. It is all high grade, well-rooted, mature and healthy. No San Jose Scale or Peach Yellows has ever been found in our nurseries. We grow every tree we offer for sale and thus we are able to guarantee it to be strictly true to name and free from all disease. We plant only the most select imported seedlings. These we plant in soil particularly adaptad to the successful raising of nursery stock. Step by step, through the various stages of cultivation and propagation, we exercise the greatest care, with the result that when the trees are mature, we have the finest and best that can be produced.

If you want stock that is true to name, the only place to buy it is from the nurseryman who grows it, and not from dealers and agents who buy their stock here and there. It is self-evident that trees handled three or four times are oiten exposed to unfavorable conditions and thus injured. After trees have passed through so many hands, who knows what the varieties are? Our nurseries are regularly inspected by a New York State Inspector and a Certificate of Inspection has been issued to us. A copy of this certificate is attached to every order shipped by us.

\section{Our Equipment}

We have gradually increased our equipment until today we believe no other nursery in the country has better facilities for handling orders whether they are large or small. All of our em. ployees are experienced and competent, many of them having been with us for years, thus grasping our ideas of how things should be done. This makes every detail of our large business work out smoothly and accurately. Our modern and up-to-date packing house contains fifteen thousand square feet of floor space and is absolutely frost proof. We have a private switch right to this packing house and thus there is no chance for our trees to be exposed or injured in any way.

\section{Our Personal Supervision}

Each department from the planting, propagating and maturing of the trees to the selling through our catalog is in direct charge of a member of our firm. Following are the names of the members and the department to which each gives his attention: James A. Kelly, selection and planting of seedlings; Edward T. Kelly, selection of scions and budding; William F. Kelly, digging and grading of trees; Richard A. Kelly, selling through catalog and correspondence; Clement A. Keily, packing and shipping of orders. It will readily be seen that in this way the best attention is given every branch of our business-better attention than could possibly be given by the most faithful and painstaking employees.

\section{Durs Cumantee}

Our guarantee is, we believe, the broadest and most liberal of any nurseryman in the country. Our guarantee means something to you, because it is backed by a firm with an established reputation-a firm that is established permanently. We guarantee our stock to be free from San Jose scale, Peach Yellows or other injurious pests. We guarantee our stock to reach our customers in good condition. We guarantee that all trees and plants purchased from us shall be TRUE to NAME as labelled. FOR ANY STOCK WHICH DOES NOT PROVE TRUE TO NAME AND AS REPRESENTED BY US, AND AS BOUGHT BY YOU, WE ARE TO MAKE GOOD YOUR LOSS OR DAMAGE BY REASON THEREOF AT ANY TIME WITHIN TEN YEARS OF THE DATE OF PURCHASE. IN EVENT WE CANNOT AGREE, WE ARE EACH TO APPOINT ONE ARBITER WHO SHALL CHOOSE THE THIRD AND THE AWARD OF A MAJORITY SHALL BE BINDING ON BOTH PARTIES. If there is any mistake on our part in regard to the stock you purchase from us we want you to tell us about it, and we will adjust the matter to your entire satisfaction. Our interest in the stock we send you does not cease when it leaves our hands. We believe our satisfied customers are our best advertisements. 


\section{Advantages of Fall Planting}

It is a fact conceded by the largest and most successful orchardists, and has been proven by the Experimental Stations throughout the country, that trees, especially apples, pears and plums planted in the fall give the best results to the planters. Fall-planted trees become firmly established in their new location before winter and as soon as the spring opens up, start growing; while with trees planted in the spring it is oftentimes a month or more before they begin to put out any root growth, although the part of the tree above ground seems to be growing nicely. Experiments at the different State Experimental Stations have proved that immediately after planting in the fall the trees begin to put out small fibrous roots which take hold firmly in the ground, thus absolutely insuring an early start in the spring. Moreover, trees planted in the fall, with their early start and vigorous growth, are better able to withstand the midsummer droughts which we sometimes have. Again, the planter is not always sure just when spring will open up in his locality, consequently, it is not always possible for him to order his trees delivered so that they will reach him at just the proper time convenient for him to plant. As it is frequently necessary, on account of the condition of the ground, to delay spring planting until May, it will readily be seen that the trees planted in the fall have a much longer growing period and will get much more satisfactory growth.

\section{Order Early}

As our orders are shipped in the rotation they are received, and as we cannot delay orders received first for orders coming later on, we advise the placing of orders early. If for any special reason it is necessary that an order be shipped on a specified date, make a note on the order and we will comply with the request if possible.

\section{Our Shipping Season}

Our Fall shipping season begins October First and continues until cold weather, but we would not advise the shipment of stock before the tenth of October as this gives the stock a chance to mature well and to harden up.

\section{How to Order}

Make out your order carefully on the Order Sheet enclosed in this catalog. Write the varieties plainly and set down the prices accurately. Specify clearly the grade and sizes of the trees desired. Indicate plainly how you want the stock shipped, whether by freight, express or mail. If by freight or express, give the name of your railroad station, also your own post office address. When specific instructions are not given we will use our own judgment.

\section{How to Remit}

Remittances should be made by Post Office Money Urder, Express Money Order, Draft on New York Bank or Registered Letter. We disclaim all responsibility unless remittances are made as above directed.

\section{Rates}

We allow ten rates on lots of five or more of a kind, such as five apples, or five plums, and hundred rates on fifty or more. It does not matter of what varieties the lots are composed. If your order amounts to $\$ 25.00$ or more, you may select everything at the lowest rates quoted, both for fruit and ornamental stock.

Cash with order except in large orders when satisfactory reference is given, ard then the order must be accompanied by one-fourth cash, and shipment will be made C. O. D. For the benefit of customers who order early, but who do not care to spare all of the money when order is sent, would say, we will accept early orders accompanied by one-third cash and reserve the stock for you. Balance of the amount to be sent when stock is ordered shipped. Prices in this catalog supersede all previous prices.

\section{Special Discount}

We will allow a special discount of $8 \%$ on all cash orders amounting to $\$ 4.00$ and up that are receive $\mathcal{A}$ on or before October fifteenth; after that date, $3 \%$ discount on cash orders of $\$ 4.00$ and up.

\section{Boxing and Packing Free}

We box and pack all orders without charge. All orders are put up in boxes or bales which are lined with heavy paper to guard against stock drying out. The trees and plants are packed in moist excelsior and straw. This is expensive, but good packing pays-pays customers, pays us. We guarantee the arrival of stock in good condition.

\section{Freight and Express Rates}

Do not be influenced by the story of the agent who says that the freight or express on your order will bring our price up as high as his. If you will consult your railroad agent you will find that the freight rates from Dansville to points east of the Mississippi, range from 20 to 40 cents per 100 pounds. First class trees will average about one pound each. Therefore, at the highest rate, 40 cents for 100 pounds, it means that you pay less than one-half cent per tree for freight. Nursery stock is carried by all express companies at a discount of twenty per cent from regular rates.

Misrepresentation of the cost of getting stock from us by freight or express is sometimes made by others. Remember, if you bought your stock delivered, or freight prepaid, the freight would be included in the purchase price. The cash discounts which we allow will, in many cases, more than cover your freight or express charges.

\section{Grading}

We guarantee every tree to be up to the grade specified, or better. Many times trees are sold by height only. This, we believe, to be very misleading as we have seen trees which belonged to the second or third grade, (if graded by size or caliper) sold for first grade, as they had the required height. We grade and sell our trees both by height and caliper, and believe this to be the only way that gives entire satisfaction to the planter. 


\section{糔 FRUIT DEPARTTMENT 糔}

\section{Apple Trees}

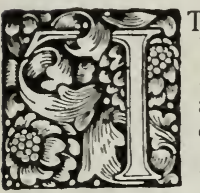

IS an established fact that of all fruits the apple is the most important. It has been rightly called the "King of Fruits." Unlike other fruits its period of ripening extends nearly throughout the year, and by judicious selection of varieties, an almost constant succession may be obtained. It is not a luxury, but a staple article of food, and the demand for good apples is increasing faster than the supply. Experienced and successful farmers and orchardists agree that there is more money in growing apples than in any other fruit, and that the orchard is the farm's greatest asset. If there is any kind of trees that we specialize in growing, it is the apple. We use the very best quality of imported French Apple Seedlings to propagate our apples on. We believe this to be of utmost importance in order that the trees may have a good foundation, be free from all disease and insure a healthy and permanent growth. We have discarded all varieties not profitable to the planter, and recommend the following varieties, giving a brief description of each.

\section{Wholesale Prices of all Varieties of Apple Trees}

Largest Size

Medium Size

Smaller Size

Largest Size

$\begin{array}{ll}2 \text { Year } & 6 \text { to } 7 \text { Feet } \\ 2 \text { Year } & 5 \text { to } 6 \text { Feet } \\ 2 \text { Year } & 4 \text { to } 5 \text { Feet } \\ 1 \text { Year } & 31 / 2 \text { to } 6 \text { Feet }\end{array}$

$\mathrm{EACH}$

.23
.18
.12

.18

\section{IEN}

$\$ 1.75$

1.35

1.00

1.35
HUNDRED

$\$ 14.00$

10.00

7.50

10.00

$8 \%$ Discount on all Cash Orders amounting to $\$ 4.00$ and up received on or before October 15 th. After that date $3 \%$ Discount on Cash Orders of $\$ 4.00$ and up.

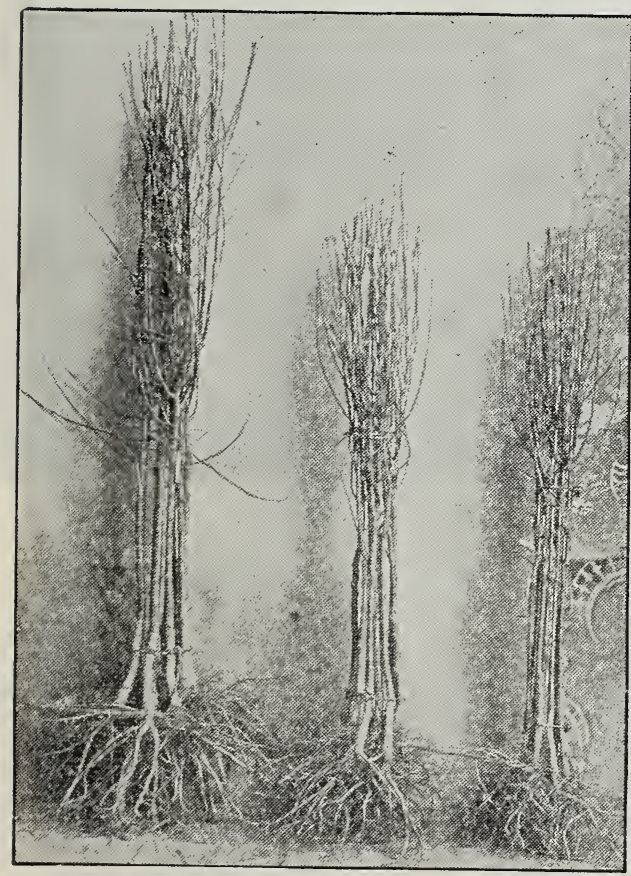

TWO YEAR OLD APPLE TREES $\mathrm{XXX}$

6 to 7 Feet $3 / 4$ and up $\begin{array}{cc}\mathbf{X X} & \mathbf{X} \\ 5 \text { to } 6 \text { Feet } & 4 \text { to } 5 \text { Feet } \\ 5 / 8 \text { to } 3 / 4 & 1 / 2 \text { to } 5 / 8\end{array}$

Note the Abundance of Fine Fibrous Roots

\section{Summer Varieties}

Early Harvest-(Yellow Harvest.) Medium to large; pale yellow; beautiful; fine flavor. Tree moderate, erect grower, good bearer; excellent variety for both orchard and garden. Ripens in August.

Yellow Transparent-Tree upright, and a very early and abundant bearer. Fruit of good size; skin clear white, turning to a pale yellow; flavor acid and very good. Ripens from ten days to two weeks earlier than Early Harvest. One of the most popular market varieties. Ripens in August.

Red Astrachan-Tree hardy and good bearer. Fruit very handsome, large, round, nearly covered with deep crimson, overspread with thick bloom; juicy and good, though rather acid; one of the best of the summer varieties for cooking. The fruit usually sells for a good price in local market. Ripens in August.

Sweet Bough-Large, pale yellow; sweet, tender and juicy. Tree a compact grower and abundant bearer. August.

\section{Autumn Varieties}

Alexander-An excellent apple for culinary use. Fruit large, firm, crisp, tender, juicy, mild sub-acid. Skin smooth, glossy, pale yellow to "orange yellow" entirely overspread with lively red stripes. Tree large, vigorous and hardy. Season September to November.

Duchess of Oldenburg-Vigorous growth ; Russian ; large ; striped ; tender, juicy, subacid ; good ; regular and abundant bearer. One of the hardiest kinds known. Ripens in Sept.

Fall Pippin-Very large; yellow, tender, juicy and rich. Tree a vigorous, free grower and fine bearer. An excellent baking apple. Ripens in October.

Fameuse-(Snow Apple.) Hardy, medium size; deep crimson; flesh is snowy white, tender, melting and delicious. Tree vigorous with dark wood; one of the finest dessert fruits, and valuable for market. Ripens in Nov. 


\section{Kelly Bros.'Wholesale Nurseries,Dansville,N.Y.}

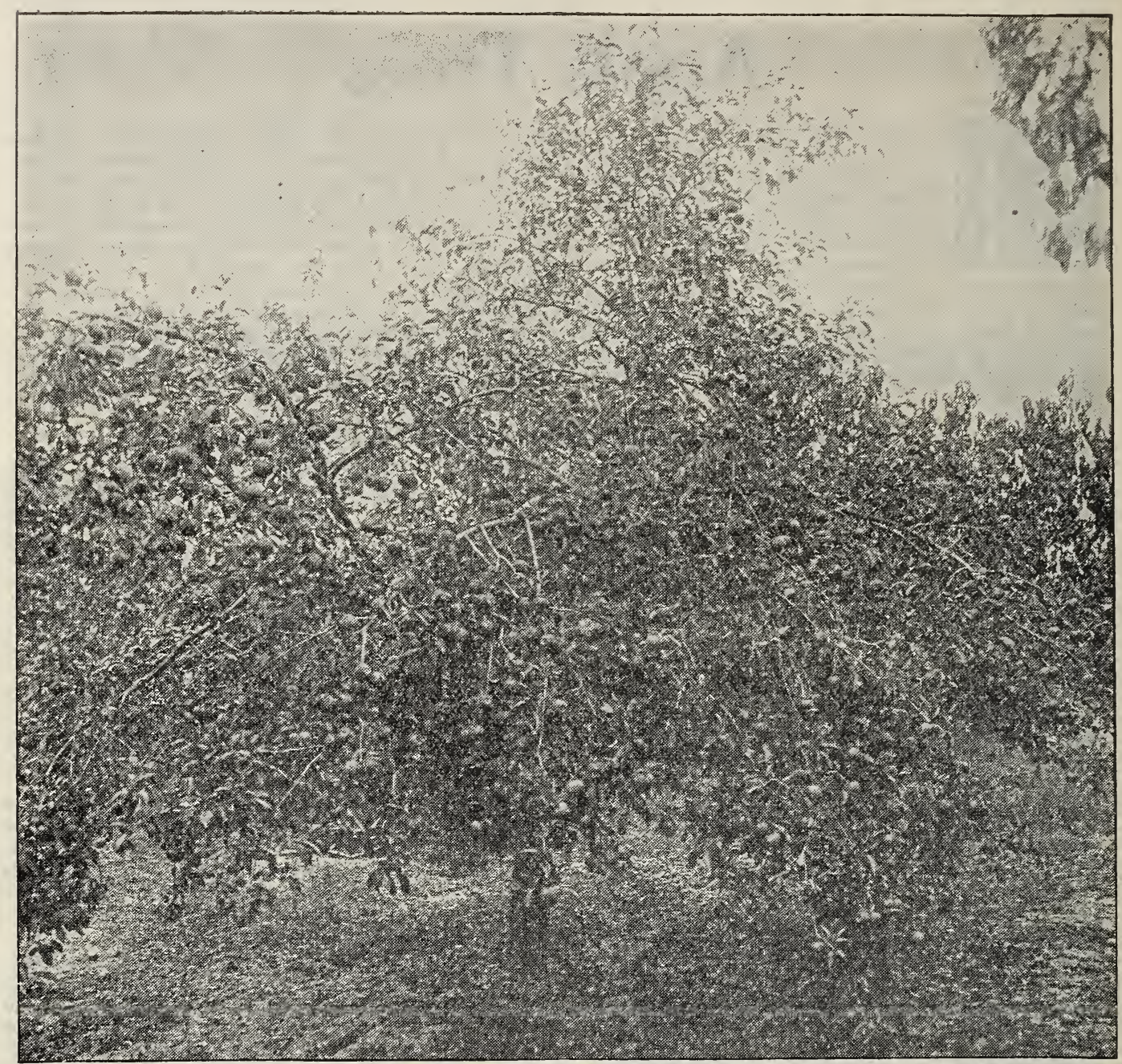

The Old Reliable Baldwin in Bearing

Maiden's BIush-Of uniformly large size, smooth, round, beautifully flushed with red on creamy yellow ground; flesh tender, of pleasant but not high flavor. A good market sort because of its attractiveness and the tree's heavy crops. Ripens in September.

Pound Sweet (Pumpkin Sweet)-A very large, round, yellow russet apple, very sweet and rich. Tree a vigorous, rapid, upright grower; valuable. Oct. and Nov.

Wealthy -This beautiful, moderate sized, brilliant red apple is of fine quality, one of the best of its season; it is a relatively good keeper and owing to the hardiness of the tree, its adaptability to cold climates, and early bearing habits, it can be profitably planted as a filler. Season Oct. to Jan.

Gravenstein-This is a large, handsome apple streaked and splashed with red over a strong yellow. The flesh is yellowish, firm, fine, crisp, tender, juicy and sub-acid. In quality it ranks very good to best. Sept. to Nov.

\section{Winter Varieties}

Baldwin-What the Bartlett pear is to pears the Baldwin is to apples for the Eastern and Middle States. No variety yields larger crops or bears shipment better, or is more attractive in color, size and shape than the Baldwin. It is esteemed as an eating apple, and for cooking. For a commercial orchard it can be relied upon. Large, bright red, crisp, juicy and rich; tree vigorous, upright and productive. In New England, New York, Ontario and Michigan, this is one of the most popular and profitable sorts for table or market. Keeps until April.

Ben Davis-A popular apple in Southern New York, Pennsylvania and Ohio. Fruit is medium to large, of a bright, deep red color, or red striped over clear yellow. Has a thin, tough skin. The flesh is whitish, firm, juicy and sub-acid. It is one of the best keeping apples on the market today, lasting in cold storage until June or July.

\section{"You'll Never Regiret}

Planting Kelly Trees" 


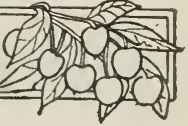

\section{Winter Apples (Continued)}

Paragon-Late keeper, large of good color and quality, very productive. Dec. to May.

wagener-(Red Winter Apple.) Wagener is one of the most beautiful winter apples ever grown. It is of the highest quality, the flesh being crisp, tender and aromatic. We know of no apple possessing greater beauty or of finer quality than the Wagener. It succeeds well East and West. Dec. to May.

Rhode Island GreeningThis large and superior winter apple is famous over a large extent of country, and is more highly prized for cooking and eating than iny other variety. It is a good keeper but will keep better if picked early. This Greening is a beautiful yellow color when ripe, and is a most abundant yielder. March to April.

Stayman's Wine Sap-Tree vigorous, hardy, spreading. An early bearer and very productive; fruit medium size, round, aporoaching conic; skin smooth, greenisil yellow, splashed and striped with red and purple; flesh yellow, firm, tender, juicy, rich, sub-acid, aromatic, quality best. Splendid late keeper.

Wolf River-Fruit is very large, some specimens weiching 27 ounces, flattened, conical, highly colored. An excellent cooking apple. Sept. to Dec.

Smokehouse-A very pleasant flavored dessert apple. Tree a vigorous grower; healthy,

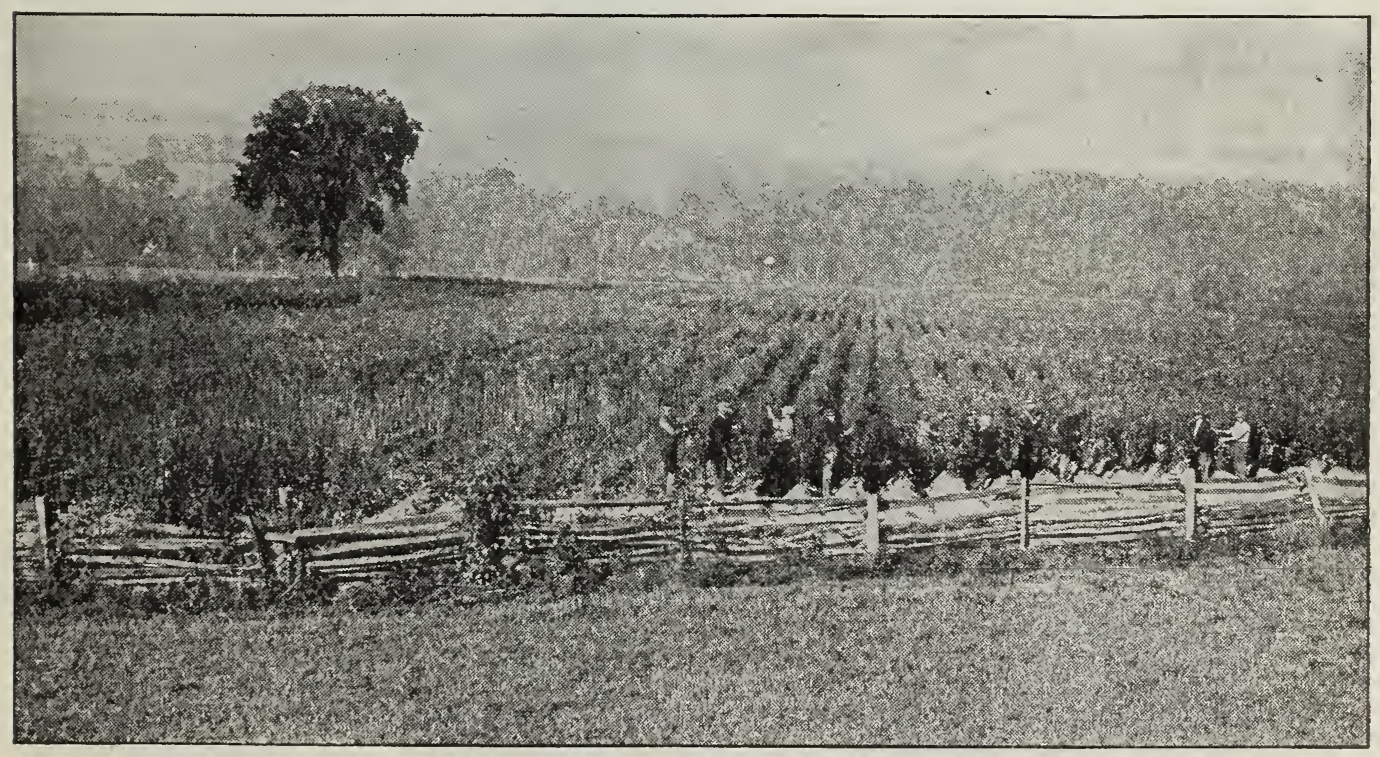

Block of 250,000 Apple Trees Growing in Our Nurseries

\section{Fall is the Very Best Time to Plant Apple Trees}


Winter Apples (Continued)

Northern Spy-This variety ranks about third in commercial importance with the fruit growers of Pennsylvania, New York and Ohio, being surpassed by Baldwin and R. I. Greening. Fruit is large and very attractive, being of bright red color with a delicious bloom ; flesh is very juicy, crisp, tender and excellent for dessert or culinary uses. Its fine reputation brings high prices in the market and the fruit is always in demand. The fruit is ready for use in November or December; keeps well in cold storage until April, or if more carefully handled, until May.

Stark-Fruit fair, smooth, uniform and attractive. Large, striped, mild, sub-acid. Valuable as a keeper. A good variety for the commercial orchard pecause the tree is thrifty, hardy, healthy, a reliable cropper and very productive. Jan. to May.

Grimes' Golden-Vigorous grower; large; golden yellow; juicy, sprightly sub-acid; very good. Keeps until April.

Gano-Similar but superior to Ben Davis. It has all the good qualities in a higker degree, more brilliant coloring, runs more even in size, and keeps fully as late. The tree is vigorous and hardy; is a rapid grower; bears while young. Color bright red without stripes or blotches, and large and even in size. Keeps until March.

Jomathan-A beautiful red apple, highly flavored and of excellent quality, being tender, juicy, spicy, and rich-a splendid family sort and highly profitable for market. Tree longlived, productive, and an early bearer. Nov. to Apr.

King-(King of Tompkins Co.) One of the largest red winter apples. It is of extraordinary size, beautiful in color, attractive, and always brings the highest market price. Its size, beauty and good flavor make it in great demand. Nov. to March.

McIntosh Red-Medium size, nearly covered with dark red. Flesh white, fine, very tender, juicy and refreshing with attractive quince-like flavor. A good annual bearer. A very hardy variety, fruit of which is very attractive in appearance, of deep red color, good size, the flesh very tender and delicious. It is especially desirable for fancy trade. It comes into bearing young, yielding large crops of good fruit almost annually.

Pewaukee - Tree spreading, round topped and vigorous. Fruit large, yellowish green, striped and shaded with dull red, overlaid with a bluish bloom. Flesh yellowish, rather coarse grained, firm, juicy; flavor sub-acid. Keeps until March.

Mammoth Black Twig-The tree is a strong grower, a regular and abundant bearer. A good winter apple. Deep red; sub-acid, very high flavored. Keeps until late Spring.

Northwestern Greening-Tree a splendid, vigorous grower, quite hardy. Fruit large to very large; green, becoming yellowish green when ripe; flesh yellow, fine grained and firm; flavor a good sub-acid; very smooth and attractive; should be given plenty of room in the orchard to secure large, even fruit. Keeps until March.

Spitzenburg-(Esopus.) Medium to large; deep red, high flavored; valuable for commercial purposes. November to April.

Tolman Sweet-Medium, pale yellow, slightly tinged with red; firm, rich and very sweet; the most valuable baking apple ; vigorous, hardy and productive. Keeps until Ápril.

York Imperial-This is a fine, hardy, large red, winter apple. It succeeds over a wide range of country. It comes into bearing at four years from planting, bears regularly and heavily. The foliage and fruit are remarkably free from scab. The fruit is of medium size, skin yellow and almost wholly covered with two shades of red, the darker one disposed in distinct stripes. Good shipper, bringing highest prices.

Hubbamdston (I'onesuch)-Free growth; large striped red and yellow; tender, juicy, rich, slightly sub-acid; very good. Keeps until January. 


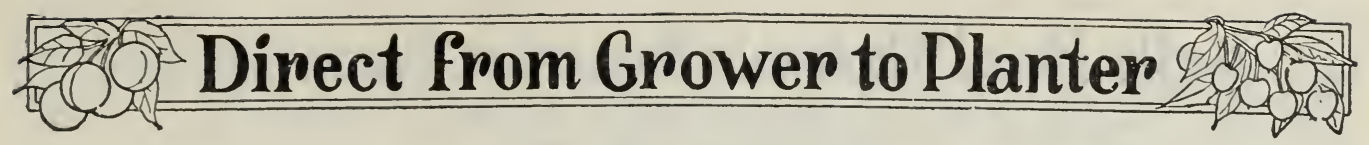

Golden Russet-Vigorous growth ; medium; russet; crisp, juicy, mild sub-acid; hardy; very good; long keeper. Nov. to Apr.

Twenty Ounce-Very large, yellow striped, red, fine quality apple; good keeper. Tree vigorous grower, productive. Oct. to Jan.

Rambo-Medium, flat streaked red and yellow; very tender, juicy and fine flavored. Tree an upright grower, hardy and productive. Oct. to Dec.

Rome Beauty-Keeps in good condition till May and June. Large, round, mottled and striped in different shades of red; flavor and quality away above the average; appearance and size are its valuable points; always sells and always brings good prices. With an established reputation due to real merit, Rome Beauty is a variety Eastern orchardists should plant largely. Good grower, blooms late, bears heav-

Winter Apples (Continued) ily every year, is adaptec. to a wide range of soils, elevations and conditions. In Ohio, Pennsylvania, New York and West Virginia will make more money than some of the sorts which are now a large part of the total number of trees in commercial orchards. Reliability, due to being frost-proof, strong-growing and sure bearing make it a favorite with the grower. Fine quality for use and for handling make it popular with consumers and dealers.

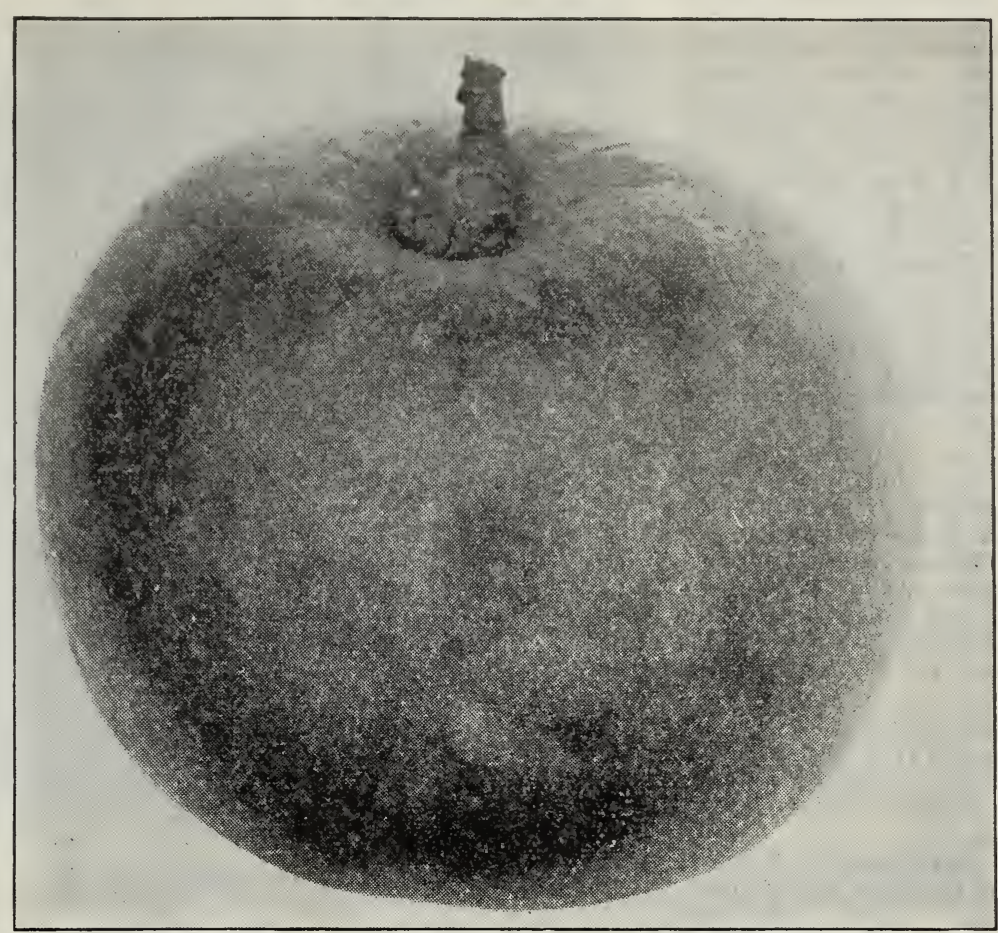

Rome Beauty Apple

When packed in boxes shows up splendidly.

Winter Banana-An excellent variety, which has stood the severest tests. Tree is hardy and will succeed in very cold climates; its wonderful productiveness will bring quicker and larger returns than any other apple in the orchard. The fruit has a richness of flavor that cannot be described. Flesh golden yellow, fine grained, firm and juicy. Keeps until January

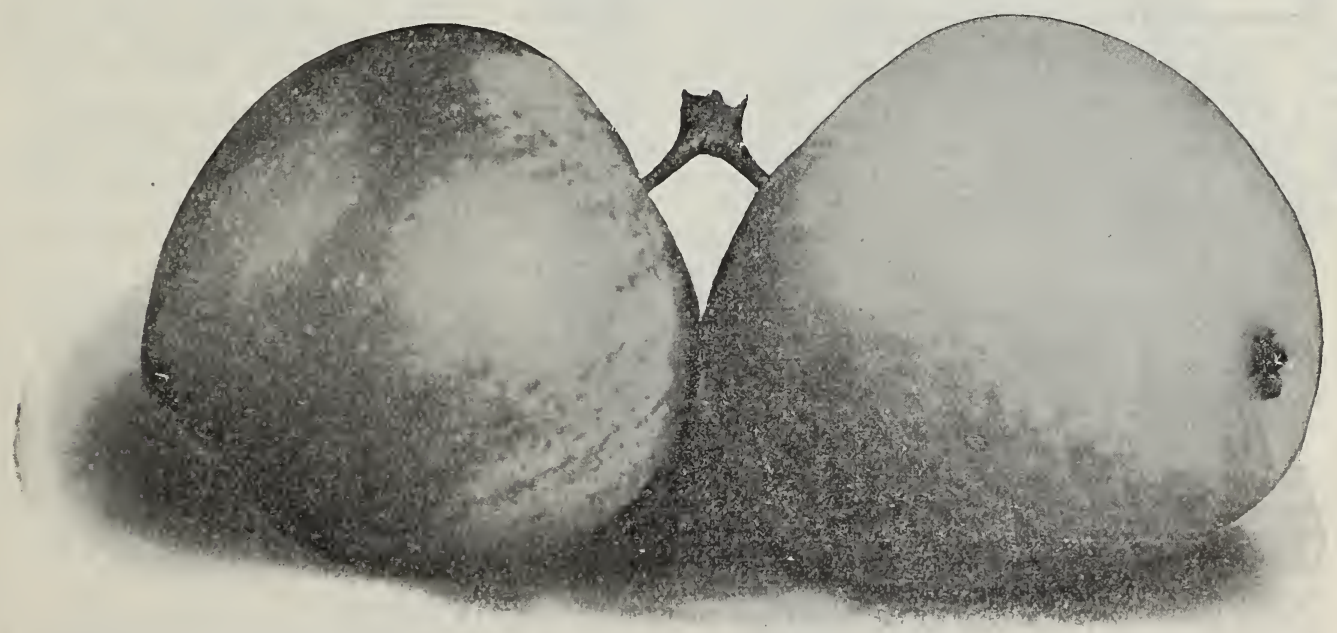

Bən Davis 
Sutton Beauty-Medium to large; roundish ; handsome, waxen yellow, striped crimson; flesh tender, juicy, subacid; good quality ; keeps well. The tree is a free grower and very productive. Keeps until February.

Fallawater - Very large, yellow with dull red cheek, juicy, crisp, pleasant, sub-acid, very productive. Dec. to Apr.

Walbridge-Fruit red striped; very attractive when colored; flesh crisp; hardy and productive, a late keeper. November to May.

Bismarck-An attractive apple, making a record for hardiness and fruiting at a very early age ; the fruit is of large size, specimens have been grown weighing nearly two pounds each fruit golden yellow, splashed with red; flesh tender.

Delicious - Winter. Of peculiar and distinctive shape; brilliant dark red, shading off to golden yellow at the blossom end ; flesh fine grained, juicy, crisp and melting, flavor sweet, with a slight acid taste. This

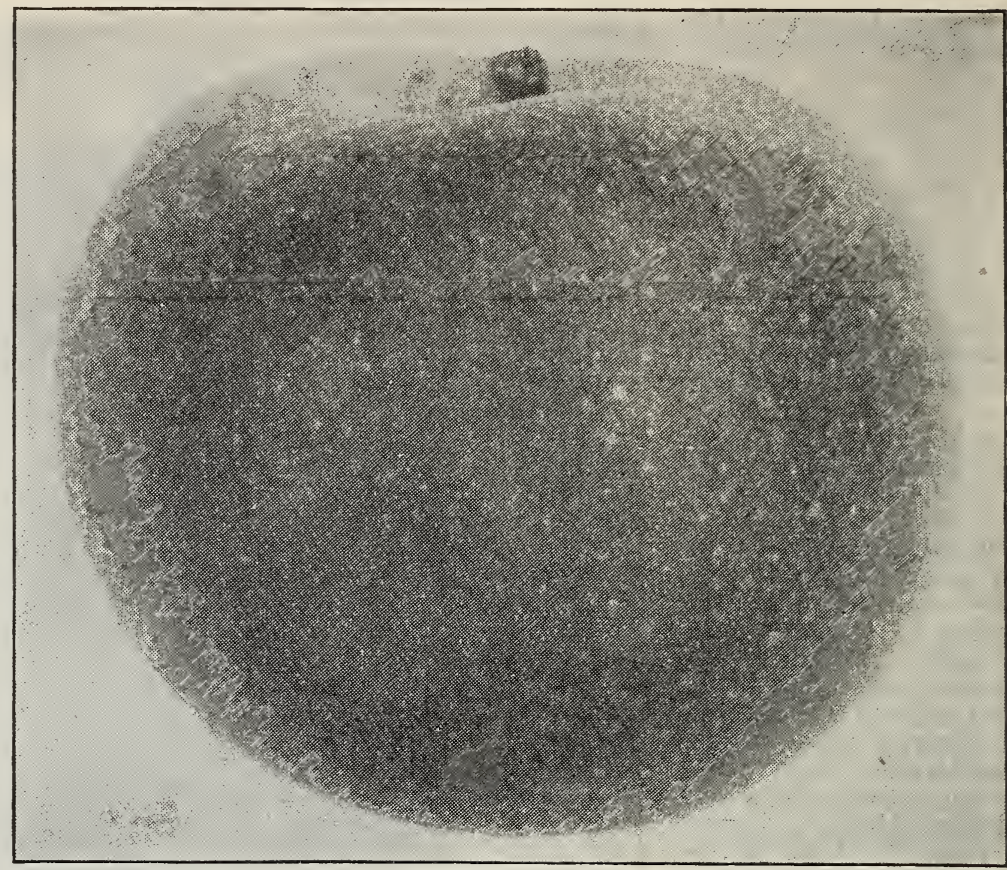

Baldwin Apple

apple is gaining in favor each year as one of the profitable commercial varieties. Tree vigorous, thrifty and a good, dependable cropper.

\section{Crab Apples}

Besides producing much .sought after fruit the Crab Apple tree is excellent for ornamental purposes. It will grow in any kind of soil and will bear every year. The Crab Apple is a prime favorite with the housewife for jellies and preserves. Many people prefer it to any other fruit for that purpose. We have the following varieties and offer them at the same price as the standard apples.

Transcendent-Remarkably vigorous, growing to a good size, and immensely productive. Bears a little the second year from planting and every year after, and produces good crops by the fourth year. The best of its class for cooking and eating; juicy and crisp. Skin yellow, striped with red. One of the best Crab Apples to plant. Ripens in September.
Whitney-Large, averaging $1 \frac{1}{2}$ to 2 inches in diameter; skin smooth, glossy green, striped, splashed with carmine; flesh firm, juicy and rich. Vigorous, handsome.

Hysıp-Almost as large as Early Strawberry Apple; deep crimson; very popular on account of its large size, beauty and hardiness. Keeps well into the Winter.

\section{TREES HEALTHY AND STRONG}

The Kelly Brothers have been growing trees for 27 years and all that time they have grown the stock they offered for sale, and they have been so determined to put out nothing but the best trees, healthy and strong, true to name and free from San Jose scale, that they have succeeded in establishing a reputation for honesty and square dealing all over the United States among the firms and individuals they have dealt with.

Their trees are grown in the Genesee valley, the best locality in the world for raising nursery stock, they have a large frost-proof brick packing house, and they will give the closest attention to orders whether large or small. They believe this of benefit to both fruit-grower and themselves, and it is quite certain if testimonials as to their reliability and promptness of attention to orders are required they can be secured from every business man and every reputable citizen in Dansville.

The Kelly Brothers offer the best trees that can be grown, they are true to name, and a fair price has been put on them so that a purchaser will know when he makes a purchase that he will get what he wants and at a moderate price.-Dansville Express, Sept. 26, 1912. 
For many years it was the popular opinion that peaches would thrive in only certain sections of the country. We know better now. With one or two exceptions it has been shown that this fruit can be grown at a good profit in every state in the Union. Peaches can be grown on any soil that will produce the average yield of farm crops and are especially adapted to the lighter soils. Careful cultivation and intelligent pruning will work wonders in the production of peaches. If properly cared for, the trees are sure to bring in a handsome return on your investment. As in other fruits it is imperative, however, that your trees are of the best stock. It is very important that wood growth on peach trees is well ripened and that they have a good and sufficient quantity of fibrous roots so they will withstand the hot sun and drought that may occur after planting. Thousands of trees are lost this way by the planter. This season we have a very good stock of hardy Northern grown trees, with well ripened wood and an excellent root system and we make the lowest possible price consistent with the quality of the stock.

\section{Wholesale Prices of all Varieties of Peach Trees}

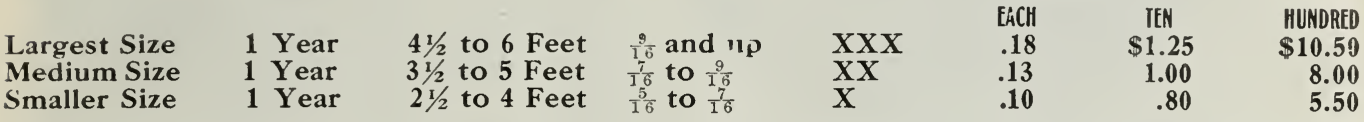

Beers' Smock-Medium to large, round; creamy-white with dark red blush; flesh yellow, tender and rich; good quality; a good commercial peach.

Carman-Middle to end of July. Fruit large and broad, oval shaped, yellowish white; flesh creamy white with red tinge, flavor spicy and good. Especially suited to low, wet land, where other sorts will not thrive. Very hardy, and productive every year. A good shipper; quite satisfactory in commercial orchards. Freestone.

Chair's Choice-Deep yellow, red cheek ; firm ; a few days earlier than Smock.

Crawford's Early-A large, yellow peach of splendid quality; strong grower and prolific fruiter. No other variety has been so extensively planted.

Crawford's Late - Superb yellow peach of large size and excellent quality; great bearer. One of the finest late varieties.

Elberta-Unsurpassed as a valuable, large, beautiful peach of good quality. The best orchard vaity. Valuable for planting in garden.

Elberta is hardier in bud than many varieties, therefore, a uniform cropper. Fruit is large, yellow, with red cheek, juicy and high flavored, flesh yellow ; freestone. Season medium early following quick upon early Crawford.

Crosby-This is considered the best variety introduced for years, and is being extensively planted through New England where hardiness is essential. Tree low and spreading. Fruit of medium size, roundish slightly flattened, with a distinct seam on the blossom end. Not so acid as most yellow peaches.

Hiley-Large white with high color on sunny side; long keeper and good shipper. Freestone, hardy in fruit bud.

Hill's Chili-Hardy, vigorous and productive; of a medium size ; oval, with a slight suture; deep yellow, shaded with dark red; flesh deep yellow, red at the stone; freestone.

Gold Drop-Large, good quality, hardy; a profitable market sort; follows Late Crawford.

Greensboro-Large, beautifully colored, bright red over yellow; flesh white; good quality, good commercial sort. July.

Niagara-Large, yellow and red; fine quality; as good as Crawford and a more dependable bearer. Very extensively grown in Western New York. Follows Early Crawford.

Yellow St. John-A desirable peach for home use and profitable for market; orange-yellow,

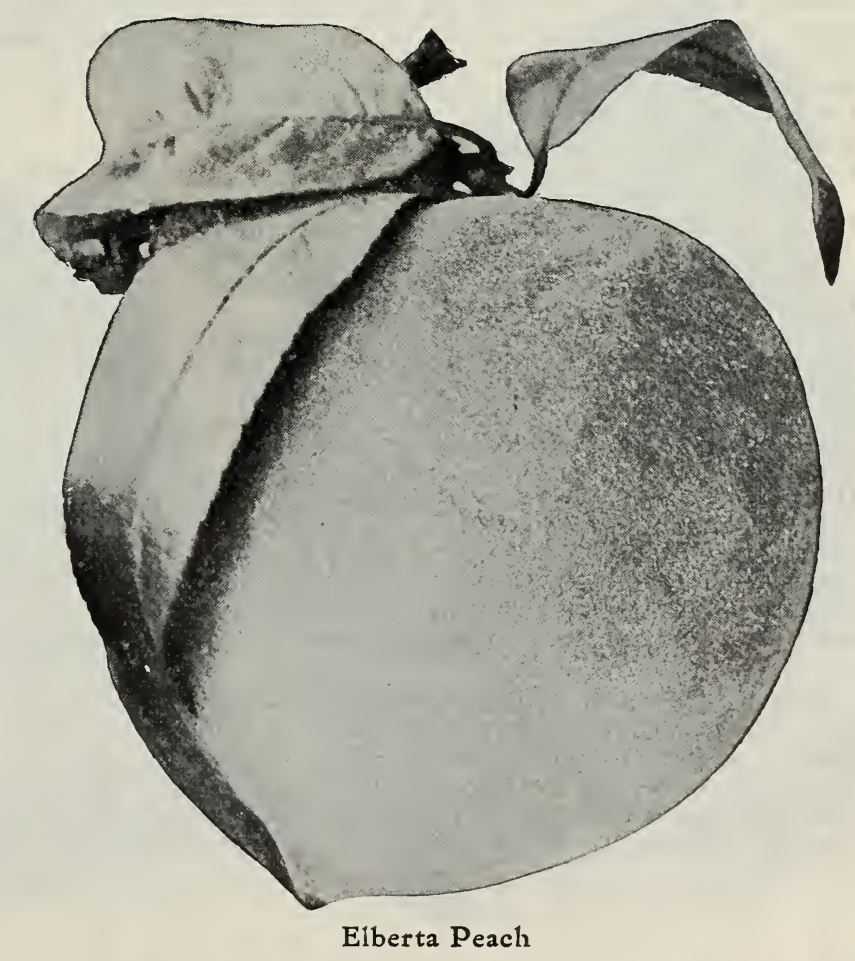

"You'll Never Regret Planting̈ Kelly Trees" 


\section{Kelly Bros:Wholesale Nurseries, Dansville,N.Y.}

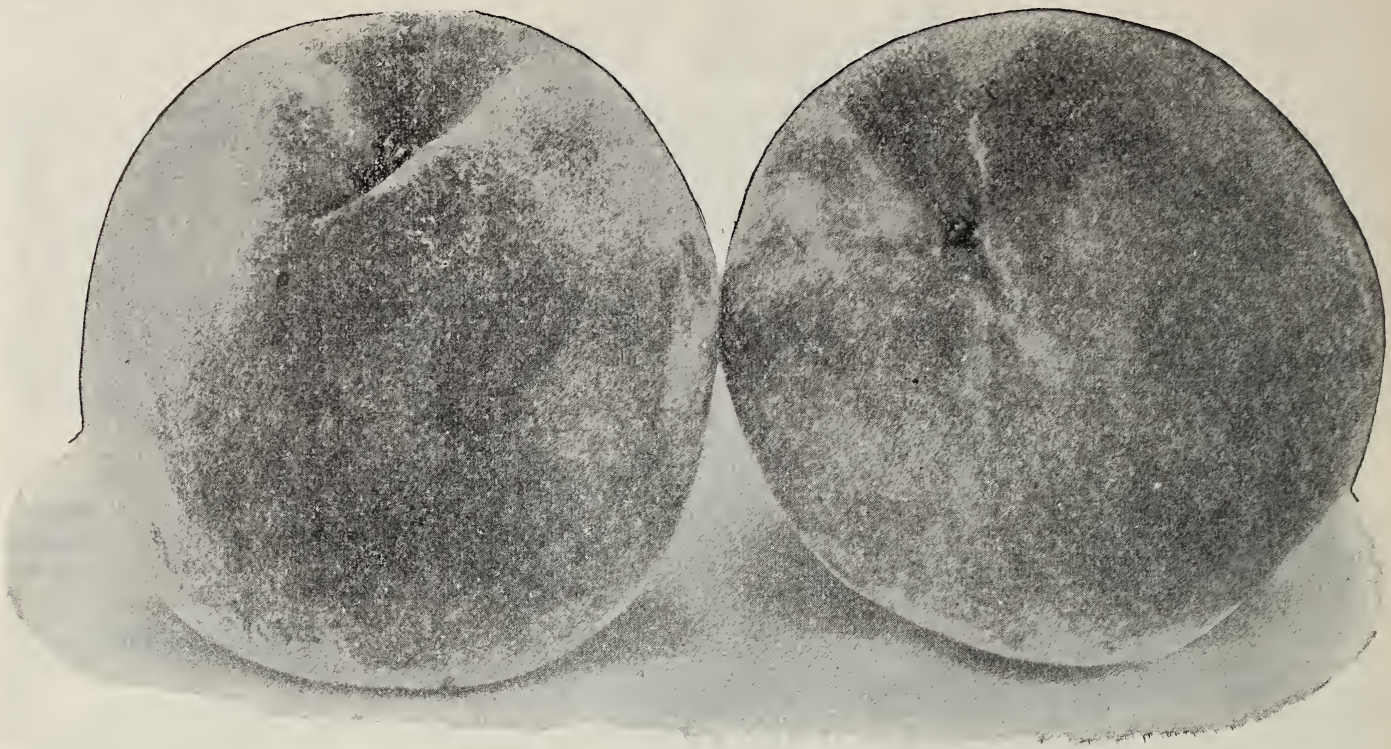

Early Crawford Peaches

with dark, rich red on sun-exposed side; quality good. Tree strong and vigorous. One week earlier than Early Crawford.

Kalamazoo-Large yellow, with mottled blush; sweet and mild; very productive; a good commercial sort.

Fitzgerald-Origin Canada. Fully equal to Crawford Ea.ly in size, quality and color, with much smaller pit; a very early bearer, often when two years from bud; extra hardy, succeeding in Canada and in Michigan perfectly; fruit large, brilliant yellow with red cheek; highest quality; ripens after Crawford's Early. Freestone.

Champion-First of August. Fruit large, creamy white, with red cheek; sweet, juicy, very high quality, and splendid. Good shipper; its fault, if anything, is that it is too tender. Hardy and productive. Free.

Foster-This variety originated near Boston, Mass., and its popularity has spread over many States. The tree is productive. The fruit is large deep red, especially on the sunny side. The flesh is yellow and very rich and juicy. It has a sub-acid flavor which is very agreeable. It ripens in September and is freestone.

Stump (or Stump the World.) Very large, roundish. The skin is white with a bright red cheek. The flesh is white, juicy and good. The tree is vigorous and productive. Ripens near the end of September and is freestone.

Belle of Georgia-First half of August. Fruit very large and most attractive in color and shape, with a light red cheek; flesh white, firm, delicious-in all ways the quality is fine. Trees grow quickly in shapely form and are very strong. Hardy, prolific. Free.
West Coxsackie, N. Y., April 30, 1913 Kelly Bros., Dansville, N. Y.

Gentlemen:-I received the trees O. K. I am very much pleased with them. They are the best I ever bought. When in need of more trees you will hear from me again, I assure you. Thanking you for your promptness in filling my order and the excellent trees you sent, I remain,

\section{Yours truly,}

$$
\text { Édwin Collier. }
$$

Kelly Bros., Dansville, N. Y.

Renfrew, Pa., April 16, 1913

Gentlemen:-The trees I ordered from you were received Saturday evening, April 12, but we did not open the box until Monday morning. We are well pleased with the trees. They are fine and arrived in good shape. The Elberta peaches are dandies. Thank you for your promptness.

Yours very truly, R. Hamilton.

So. Hatfield, Pa., May 3, 1913 Kelly Bros., Dansville, N. Y.

Gentlemen:-I received my trees yesterday and they were in fine condition. I want to say that I am more than pleased with them. I think they are the finest lot of trees I ever received from any nursery.

Yours very truly,

W. Chester Angle.

Fitchburg, Mass., April 28, 1913: Kelly Bros., Dansville, N. Y.

Gentlemen:-I received the trees all right sometime ago. I have been buying trees for 35 years. I think these are the best lot of trees I ?ver bought.

Yours truly,

Geo. F. Williams. 


\section{Direct from Grower to Planter}

\section{Pear Trees}

While fruit experts agree that apples are the most important fruit of the wcrld, these same authorities will tell you that if produced under the right conditions there is no better truit to srow than pears. Compared to apples, there are few really fine pears on the inarket. Growers who woull specialize in this fruit and produce the best varieties, would be well repaid for their efforts. The high prices obtainable for choice pears attest the truth of such 2 s assertion. There are thousands of people who prefer pears to any other fruit, and they are able and willing to pay well for the best varieties. Our pears are all budded on imported French stock which gives them an excellent root system. At present we have a good supply of the following varieties :

\section{Wholesale Prices of all Varieties of Pear Trees}

\begin{tabular}{|c|c|c|c|c|c|c|c|}
\hline $\begin{array}{l}\text { Largest Size } \\
\text { Medium Size } \\
\text { Smaller Size } \\
\text { Largest Size }\end{array}$ & $\begin{array}{l}2 \text { Year } \\
2 \text { Year } \\
2 \text { Year } \\
1 \text { Year }\end{array}$ & $\begin{array}{l}6 \text { to } 7 \text { Feet } \\
5 \text { t' } 6 \text { Feet } \\
4 \text { to } 5 \text { Feet } \\
31 / 2 \text { to } 6 \text { Feet }\end{array}$ & $\begin{array}{l}3 / 4 \text { and up } \\
5 / 8 \text { to } 3 / 4 \\
1 / 2 \text { to } 5 / 8\end{array}$ & $\begin{array}{l}\mathbf{X X X} \\
\mathbf{X X} \\
\mathbf{X} \\
\mathbf{X X X}\end{array}$ & $\begin{array}{l}\text { LACH } \\
.25 \\
.20 \\
.15 \\
.20\end{array}$ & $\begin{array}{l}\text { IEN } \\
\$ 2.20 \\
1.75 \\
1.25 \\
1.75\end{array}$ & $\begin{array}{r}\text { HUNDRED } \\
\$ 19.00 \\
14.00 \\
11.00 \\
14.00\end{array}$ \\
\hline
\end{tabular}

\section{Summer Pears}

Bartlett. Rich golden-yellow when ripe, often with a soft blush; larege, thin-skinned; buttery and melting, with a rich musky flavor. Tree a strong grower, bears young and abundantly, but roquires careful cultivation to bring it up to its highest excellence. Probably more highly esteemed for canning and shipping than any other. Succeeds best as standard, but does well as dwarf. An old favorite. When planting orchards of standard Bartlett, it is recommended that dwarf Bartlett or dwarf Anjou be used for fillers, since it greatly increases the profit. In planting dwarf pears, they should be set into the ground deeper than the standard trees, the union should be 4 to 5 inches below the surface.

Clapp's Favorite. Large, fine; pale lemonyellow, with brown dots ; fine texture, melting, buttery, juicy, with a rich, sweet, delicate, vinous flavor. Tree hardy and very productive. Thrives where other varieties fail.

Wilder (Summer variety). Medium to small, greenish yellow with a brownish red cheek; melting, sweet and very pleasant; tree a viaorous grower and good bearer.

\section{Autumn Pears}

Anjou (Beurre de). This is one of the best known, most popular and profitable pear. The tree is a vigorous grower, hardy and prolific. The pears are of large size, green in color, but often yellowing when thoroughly ripe. They are very juicy and luscious and of the best quality. For late fall and very early winter use, we have no better variety. Oct. to Jan.

Sheldon. A large, round, russet and red pear of very f i n e quality, melting, rich

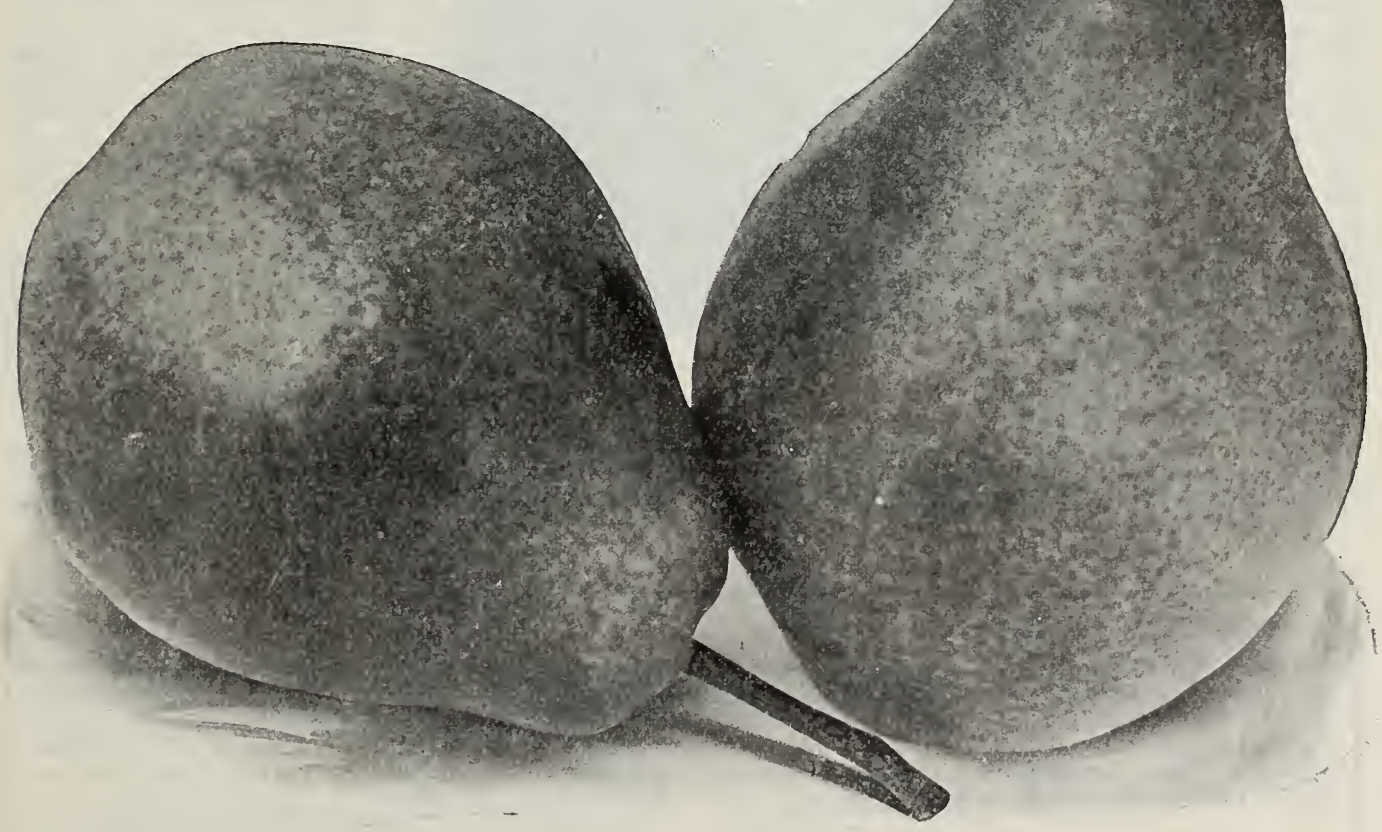


and delicious. Tree vigorous, erect and handsome, bears well and should be more largely planted. October.

Duchess d' Angouleme. A most dependable cropper, often fruiting the first season after plantino Fruit large, frequently weighing a pound. A dull greenish yellow, spotted russet, flesh white, rich and good quality. An all around profitable market pear. Oct. and Nov.

Flemish Beauty. This fine old pear is still one of the hardiest and most generally successful over a wide range of country, producing good crops annually of large, handsome fruit that is expectionally good in quality. Considered one of the hardiest and best for the northwest in which location it bears great crops of perfect fruit.

Kieffer. Large, rich golden yellow, sometimes tinted red on the sun-exposed side; fair quality, excellent for canning. I乞 has become a profitable market variety on account of its good shipping and keeping qualities. To properly ripen should remain on the trees until leaves begin to fall, then gather carefully and allow to ripen in a cool dark cellar, or other place of eve $n$ temperature. Tree a most vigorous grower, an early bearer, one of the most resistant to blight, very prolific, and widely planted throughout the country. The tree is so hardy and free from insect pests as to give it greater value than most other varieties. The fruit

is of high color and great beauty and sells more readily than fruits of better quality. Some praise it very highly, while others do not think so much of it, but large fruit-growers are planting whole orchards of it. Fruits should be thinned. Ninety per cent Kieffer and ten per cent Le Conte or Garber should always be the arrangement, on account of pcllenizing. The most practical sort for commercial Pear orchards. Oct. to Nov.

Seckel. A beautiful and delicious little Pear that is the standard of excellence in its class. One of the richest and highest flavored Pears known, always in demand for desserts and luncheons and better known than any Pear of its class. The tree makes a somewhat slow but stout and erect growth. Sept. and Oct.

worden-Seckel. This beautiful and delicious pear attracted wide attention when introduced recently. In quality it is rated very high. In size it is much larger than Seckel. It is shaped like Bartlett but is not as large. A tree of this beautiful pear is an object of beauty on the home ground when laden with beautiful specimens. Oct.

Lawrence. Trees hardy, healthy and very productive. Fruit large ; skin yellow, covered with brown spots. Fles h whitish, rich, buttery, and aromatic. One of the quality pears that nas great merit for commercial orchards.

Garber. Trees free from blight and immensely productive. Fruit large, resembling Kieffer, but ripening two or three weeks earlier. Oct. to Dec.

Vermont Beauty. Tree hardy and vigorous. Fruit round, of medium size; skin yellow, nearly covered with carmine-pink; flesh melting and rich. October.

Louise Bonne de Jersey. Large size, pale green in the shade but overspread with brownish red in the sun; very juicy and melting with a rich and excellent flavor. Good commercial sort. September to October.

Barseckel. A cross between Bartlett and Seckel. Vigorous, upright grower. Fruit large, smaller than Bartlett, ripening later. Skin pale green; flesh fine grained, melting and juicy.

TO OTHER FRUIT GROWERS :

Downington, Pa., Jan. 4, 1913

I went up to Dansville Oct. 20, 1912 with the intention of staying to see my trees dug and shipped. After a couple of days of looking around, I decided to place my order of some 6000 trees with Kelly Brothers as they had the varieties I wanted and large blocks to select from. Most of all they would begin at once on my order. The trees came in time to plant in the fall and they were most carefully packed. I am also satisfied that my varieties are true to name as I know the standard varieties I use by their characteristics.

ChARLES G. CRAWFORD, Horticulturist. 


\section{Read What Some of Our Customers Say}

Here are only a very few of the many unsolicited letters we liave received from our cusiomer: testifying as to the quality of our stock, prompt attentioll in filling orders, and fair dealing. Read them :

Kelly Bros., Dansville, N. Y.

Marlboro, Mass., May 12, 1914

entlemen :-

Iy 500 trees, 2000 raspberries all 1000 strawberries liave all arrived in good condition. I want especially to thank you for tlie good quality of the apple trees. Although have planted hundieds I have llever received any that liad such yood root system as yours, even thougl I have some times paid five times the price of tliese. In fact, the price for your trees was so low that I was rather afraid to order from you until I had written to someone wlio I knew had purchased from you, and bad their assurance that your compans was all right. Now I am ready to state that your company wau an company can be ril say they witli. Thanking you for sending me such good stock, and witl. Thanking you for sending me such good

assuring you of my future patronage, I am,

$$
\text { RALPH F. BARNES. }
$$

Kelly Bros.. Dansville, N. Y.

Mason, Mich., Mar. 9, 1914

Gentlemen:highest compliment I can pay the stock received is the order which I am enclosing herewith.

$$
\text { Respectfully. }
$$$$
\text { Ashville. N. Y., Apr. ₹, } 1914
$$

Kelly Bros., Dansville, N. Y.

Gentlemen :-

Ship me at once the enclosed order. Of the 2200 I bought last spring I lost but 20 trees and 8 of those were killed by rabbits or mice. Yours truly,

$$
\text { O. A. HEFF. }
$$

Kelly Bros., Dansville, N. Y.

Lewiston, La., Mar. 2, 1914

Gentlemen :

1 recelved my trees and plants in good condition and am well pleased with their appearance.

$$
\text { Yours truly, }
$$

Sanborn, N. Y., Apr. 29, 1914.

Kelly Bros, , Dansville, N. Y.

Received your nursery stock today in good order. Am very much pleased with it. The trees are the best $\mathrm{I}$ ever bought. I do not see how you can grow such trees and sell them at that price. Furthermore, I thank you very much them at that price. Furthermore, I thank you very much for the extra apple trees. When I

$$
\text { G. L. WENDT. }
$$

Summeriill
Messr's. Kelly Bros., Dansville, N. Y.
Gentlemen:-

Summersille, S. C., June 16, 1914.

The fruit trees you recently shipped me arrived in fine condition. I thank you for the complimentary trees. I assure you that whenever the opportunity presents itself I shall bespeak a word in your behalf.

$$
\text { Yours respectfully, }
$$

$$
\text { O. F. REENSTJERNA. }
$$

Kelly Bros., Dansville N. Y.

Sterling, Ill., Apr. 20, 1914

Gentlemen :-

I received trees which, by the way, were packed better and neater than any I ever obtained elsewhere. When ordering I neglected to state that I expected to use trees as specimens on lawn, but on opening package I found that every one was practically perfect, with unusually strong roots. I am more than pleased with shipment. Truly yours

$$
\text { L. A. BitToRF. }
$$

Kelly Bros.. Dansville, N. Y.

Brocton, N. Y., Apr. 6, 1914.

Gentleinen :certainly fine stock, nicely packed, and are in every way up to your advertising claims. In the future I shall give you my orders. Very truly yours,

$$
\text { STETART DEAN. }
$$

Kelly Bros. Nurseries, Dansville, N. Y

Lovells, Mich., Apr. 13, 1914. Gentlemen :-

Today I received the trees I ordered from you. They are far better trees than I have been buying of other nurserymen. Kelly Bros. are O.K. Yours truly,

CHAS. W. MILLER. fuffersollstow1, Ky., Ap: 16, 1914

Kelly Bros., Dansrille, N. Y.

eutleuen:

Trees received and they were in good shape. Tliey looked as if they hat just beell packed. They are a fine lot of trees-fine loots and elrgant tops and bodies. I have bought a lot of trees from nurserymen but Kelly Bros. lay it over all others. I will send you another order in the fall or next spring. Thanking you for good count and the extra bullch you give $m$. and wishing the Kelly Bros. success for the year 1914, I ain, Your's respectfully,

\section{MILLER}

Kelly Bros., Dansville, N. Y.

Himpden. Mass, Apr. 18, 1914

Nursery stock arrived safely and in good condition. thank you for the prompt shipment of this splendid stock. They certainly are the very best trees.

Yours truly.

E. NORTON DATIS.

Kelly Bros., Dansville, N. Y

Palaskl. N, Y., May $千, 1914$.

Gentlemen :-

The trees I ordered from you came in fine shape and so far are very satisfactory In $\mathrm{mv}$ order I stated that? would like them about May 1st-they cane Apr. 30 th. That is what I call prompt shupment. Yours truly

$$
\text { C. J. Wightмa. }
$$

Newfound, IV. Va., Apr. 13, 1914

Kelly Bros.. Dansville, N. Y'.

Gentlemen :-

The Club order containing more than 500 trees pur chased from you and shipped March 25th arrived at our $\mathrm{R}$ $R$. station in good condition April 8th and were hauled and delivered on the 10th and 11th. Every one well pleased. The first class trees in the order are the flnest and largest trees ever brought to this county.

Yours very truly.

(REY.) G. B. Goode.

Kelly Bros., Dansville, N. Y

Samaria, Mich., May 12, 1914

Gentlemen., Dan

I received the trees all right. I bought trees of four different people and yours were the nicest of any of them. Yours truiy, T. BELL.

Brighton, Ont., Can.. May 17, 1914.

Messrs. Kelly Bros., Dansville, N' Y

Gentlemen :-

The trees arrived in excellent condition and are all that you in your catalog claim for them. You certainly

will secure more orders from this district the roming
spring.
Yours truly, JAS. A. FindLAY. spring. $\quad$ Yours truly,

Kelly Bros., Dansville, N. Y.

Wilton, ‥ H, May 2, 1914.

Dear Sirs:-

Our trees came in good condition. They were surely packed in a thorough way. We are much pleased with the quality of your stock and I shall be only tou glad to recommend you to my friends, or to any one inquiring for nursery stock. Thanks for extra trees.

$$
\begin{aligned}
& \text { Yours very truly, } \\
& \text { ELMER B PARKER }
\end{aligned}
$$

Dry Creek, W. Va., Apr. 10, 1914

Kelly Bros., Dansville, N. Y

Dear Sirs : -

I received my nursery stock O. K., and the stock is much larger and better than I was expecting.

$$
\text { Yours truly, }
$$

Kelly Bros., Dansville, N. Y

Tyler Hill, Pa., May 4, 1914

The nursery stock I bought of you I find is just what you advertise-True to Name. I am certainly very much pleased with the looks of the trees, Have had several parties tell me the Kelly Bros,' trees are all right. Berry bushes also look fine. I will favor you with my future order. Yours truly.

$$
\text { MORT IVEBR. }
$$

Siloam Springs, Ark., March 21, 1914 Kelly Bros., Dansville, N. Y.

Trees arrived promptly and in good order, Am very much pleased with them. They are very nice. Thank. for the gratis trees. Yours,

H. W. HUBBARD. 


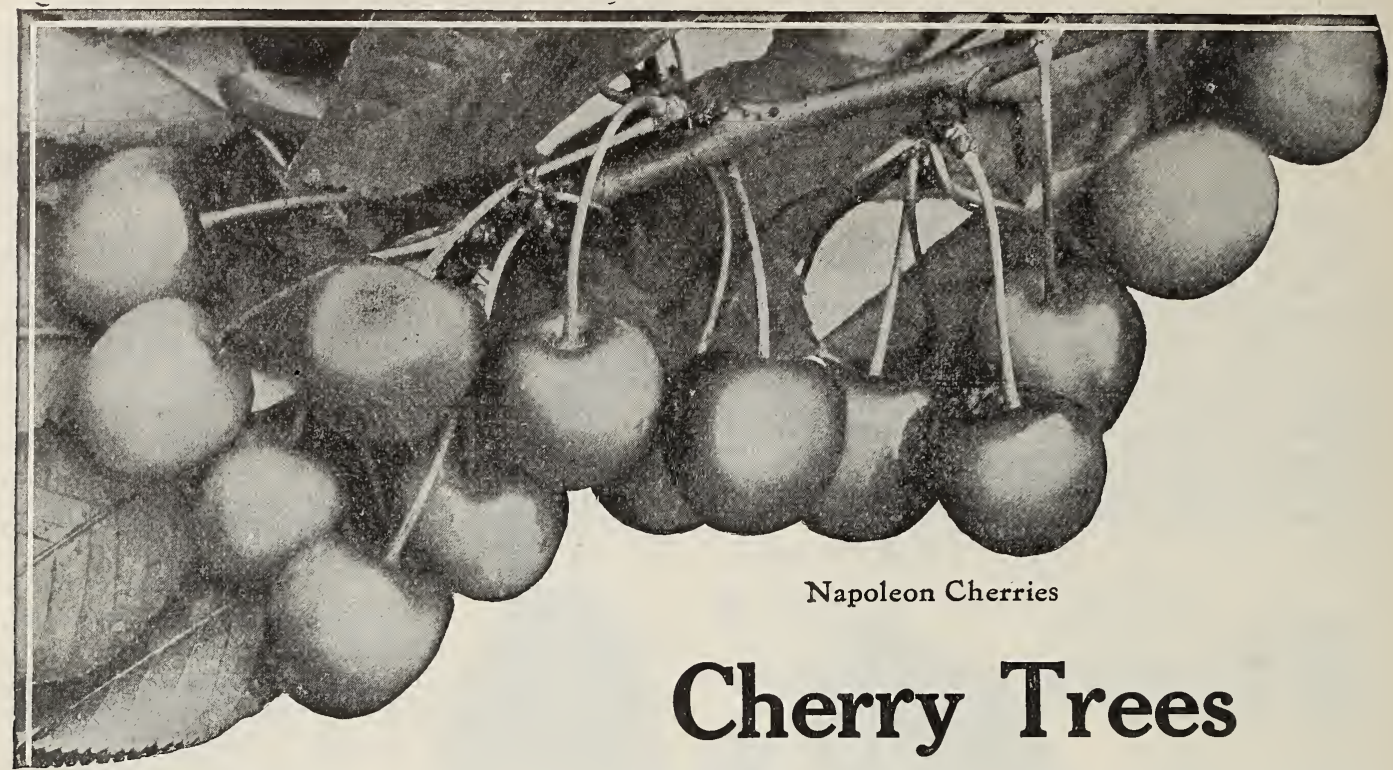

The Cherry does best on a sandy or gravelly soil, but will thrive on almost any soil that is not extremely wet. On account of its rare beauty as a shade tree (as well as being a producer of delicious fruit), the Cherry tree is very desirable for planting around the home. No other fruit will bring greater profits, as the Cherry tree will bear fruit two years after planting, and requires very little care and attention. Do not hesitate to plant Cherries because you fear there will be no market for them-the market is waiting and will be very willing to take the Cherries as soon as you have them. People who are accustomed to the little, inferior fruit never stop looking when they see Cherries of improved varieties. Our trees are all budded on imported French Stocks and these form a healthy fibrous root which reduces considerably the loss in planta.j. We have a good assortment of the best varicties and would especially recommend Early Richmond and Montmorency for commercial planting.

\section{Wholesale Prices of all Varieties of Cherry Trees SOUR GHERRIES}

Largest Size

Medium Size

Smaller Size

Largest Size
2 Year

2 Year

2 Year

1 Year
5 to 7 Feet

$41 / 2$ to 6 Feet

4 to 5 Feet

3 Feet and up

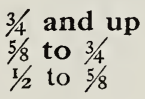

$3 / 4$ and up

$1 / 2$ to $5 / 8$

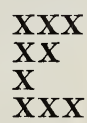

$\mathbf{X X}$

XXX

EACH
.25
.20
.15
.20

.25
.20
.15
.20

$\begin{array}{cr}\text { TEN } & \text { HUNDRED } \\ \$ 2.25 & \$ 22.00 \\ 1.90 & 17.00 \\ 1.35 & 12.00 \\ 1.90 & 17.00\end{array}$

17.00

\section{SWEET CHERRIES}

Largest Size

Medium Size

Smaller Size

Largest Size

\begin{abstract}
2 Year
2 Year

2 Year

1 Year
\end{abstract}

6 to 7 reet

5 to 6 Feet

4 to 5 Feet

$31 / 2$ to 6 Feet

$\begin{array}{ll}3 / 4 \text { and up } & \mathbf{X X X} \\ 5 / 8 \text { to } 3 / 4 & \mathbf{X X} \\ 1 / 2 \text { to } 5 / 8 & \mathbf{X} \\ & \mathbf{X X X}\end{array}$

$$
\begin{aligned}
& \mathrm{EACH} \\
& .30 \\
& .25 \\
& .20 \\
& .25
\end{aligned}
$$

HUNDRED

$\$ 24.00$

21.00

16.00

21.00

\section{Sour Cherries}

Early Richmond-One of the most valuable and popular cherries unsurpassed for cooking purposes. It is the good old variety that yields such marvelous crops in the gardens. The most hardy of all varieties, uninjured by the coldest winters. Tree slender in growth, with a roundish spreading head, exceedingly productive. Ripens through June. The cher"y tree bears almost every year, and is an easy fruiter.

May Duke-This is one of the good old standbys which has been so popular for many years in the past, both in the East and West, where it has been largely planted and where it has rewarded the planter by large crops of profitable fruit. The color of this cherry gradually changes from a bright red to nearly black when fully ripe. The flesh is red, becoming dark purple later; is very juicy and melting, rich, acid and of superior quality. It must remain on the tree until fully ripe in order to develop its best character. Season very early. The tree is very hardy and adapted to all localities.

Large Montmorency-This is the best of all the sour varieties of Cherries. There is a greater demand on the market for this Cherry than for

SEE OUR SPECIAL COLLECTIONS ON LAST PAGE "Youll Never Regiret Planting Kelly Trees" 
any other. The trees are the cleanest and best growers and are less subject to disease, less affected by wet weather, and are the best bearers of the best fruit of all other sour varieties. No matter how unfavorable the season may be, Montmorency can be depended upon for a full crop. The Montmorency is a good shipper, very attractive looking and always brings good prices. The canning factories are always calling for them and want them by the hundreds of tons. The fruit is good sized, fine flavored and bright clear shining red. The flesh is of fine quality and sub-acid. Fruit ripens 10 days after Early Richmond.

Dyehouse-A hardy and valuable cherry Unquestionably the earliest cherry, ten days earlier than Richmond, fine quality, its early bearing remarkable as its great hardiness. Has the appearance of being covered with a scarlet cloth such is the abundance of the fruit. Has the smallest pit of any cherry known; a spleudid keeper and free from knots. For tarts, pies and especially for canning, it has no superiors among cherries. June.

Ostheime-Large; skin red, dark at maturity; flesh liver-colored; tender, juicy, almost sweet; very good; hardy.

Wragg-Large, roundish, heart-shaped dark crimson and when fully ripe, black or nearly so: flesh and juice light crimson, firm and good, very productive; one of the hardiest and is usually a sure cropper.

Olivet-A tree of this variety should be in every garden. The fruit is very large, has a shining deep red color; tender, mild sub-acid flavor. Ripens in June.

English Morello-Fruit large elongated; almost blackish red when fully ripe; very rich, acid; juicy and good. A splendid pie cherry. Tree very hardy, somewhat smaller than other sorts but exceedingly productive. This fruit is in great demand by the fruit-juice manufacturers. July.

\section{Sweet Cherries}

Bing-One of the most delicious Sweet Cherries grown. Tree very hardy and vigorous with heavy foliage. It succeeds in the East better than most sweet varieties. Fruit is large, dark brown or black and very fine quality. Bing is a good shipper and should be planted with Lambert for commercial purposes.

Black Tartarian-Very large; bright purplish black; half tender; juicy, very rich. Tree a remarkably vigorous and erect grower, and an immense bearer. One of the most popular varieties in all parts of the country. June.

Yellow Spanish-A pale yellow cherry with bright red cheek in the sun. It is one of the best, most beautiful and popular of all of the light colored cherries; vigorous and productive.

Windsor-Tree upright, vigorous and a rapid grower; fruit large, roundish, oblong; very

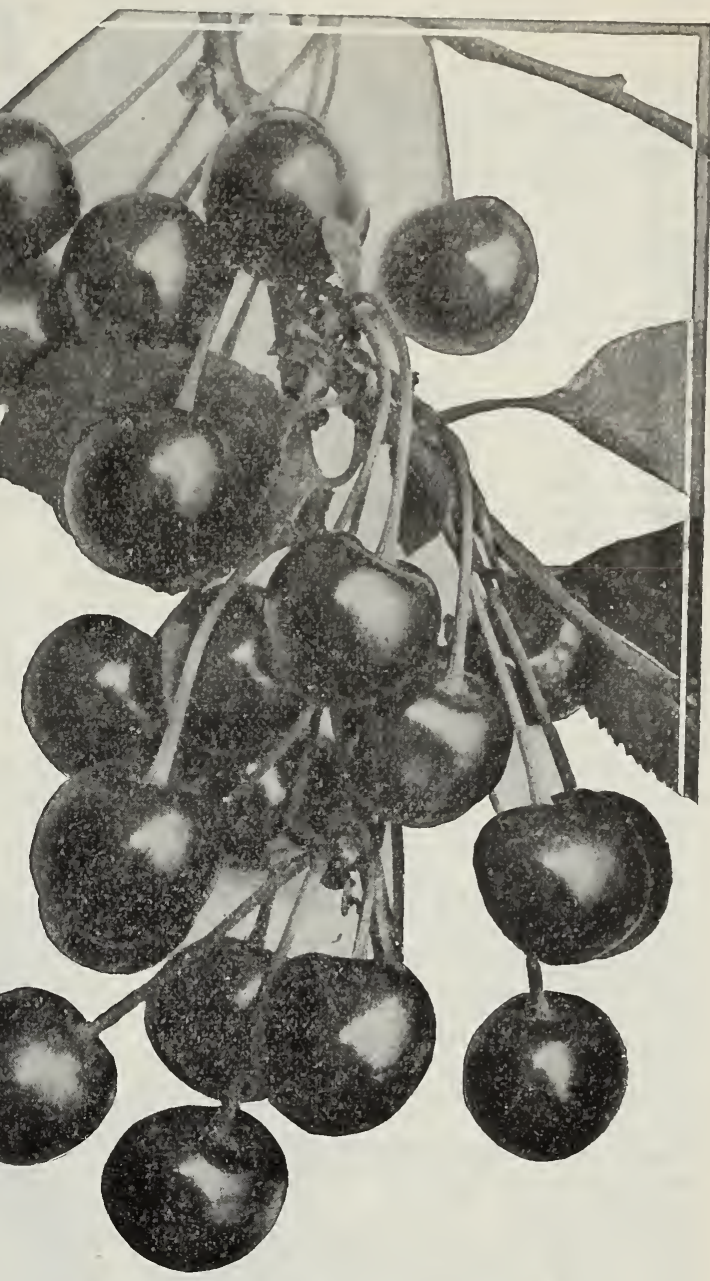

Large Montmorency Cherries

firm and juicy; flesh pinkish and sometimes strealked; quality very good; a productive bearer; has attracted attention owing to its large size and dark color; almost black. July.

Schmidt's Biggarreau-The fruit is of very large size, of a deep mahogany color. The flesh is dark, tender, very juicy, with a fine rich flavor. Fruit grows in clusters. it is an excellent shipper. July.

Governor wood-Large, heart-shaped; light yellow, marbled light red, juicy, sweet and rich. Tree vigorous, productive ; forms a round head. An old variety that is still a favorite in many regions.

Napoleon or Royal Ann-A beautiful cherry of large size; pale yellow with bright red cheek; flesh firm, juicy and sweet; one of the best for market and canning.

Lambert-One of the largest of all Cherries. It is purple-red; firm and rich. Every year sees an enormous crop, and the tree not only grows well, but is a proof against insect and fungous attacks. The finest of shippers. 


\section{Kelly Bros'Wholesale Nurseries,Dansville,N.Y.}

\section{Plum Trees}

No other fruit tree, unless it is the-cherry, will produce more abundantly than a plum tree. Although they will yield crop after crop despite neglect, plum trees will readily show the result of care and modern methods of fruit growing. The commercial side of plum production has received much attention in late years but the supply still falls far short of the demand. In general, plum trees thrive best in a sandy or clayey soil. A distance of 12 to 15 feet apart is considered the best for plum trees with the distance increased to 20 feet where a wagon spraying outfit is used. Many varieties of plums produce so abundantly that the best results will be obtainable only by careful thinning. If allowed to grow naturally the trees will be weakened and the quality of the fruit will be inferior. We can recommend to the planter the following varieties.

\section{Wholesale Prices of a!l Varieties of Plum Trees}

$\begin{array}{lll}\text { Largest Size } & 2 \text { Year } & 6 \text { to } 7 \text { Feet } \\ \text { Medium Size } & 2 \text { Year } & 5 \text { to } 6 \text { Feet } \\ \text { Smaller Size } & 2 \text { Year } & 4 \text { to } 5 \text { Feet } \\ \text { Largest Size } & 1 \text { Year } & 31 / 2 \text { to } 6 \text { Feet }\end{array}$

\section{European Plums}

Bradshaw-A very large and fine early plum, dark violet red, juicy and good. Trees erect and vigorous; very productive; valuable for market. The quality is excellent, and it is destined to become one of the most popular of all plums for canning, while its attractive color, good quality and shipping properties will cause it to be sought for as a market variety. It ripens ten days to two weeks later than Abundance. This plum resembles Niagara in size, color and general good qualities.

Fellemburg Prune-Dark purple with a dark blue bloom; size medium; oval, pointed and tapering. Flesh juicy and delicious ; fine for drying. In the West it is grown by the thuusands of acres and shipped by the trainload to all markets of the world.

Geuii-Very large, bluish purple; flesh yellowish green, sweet. Tree hardy and rapid grower.

German Prune-A valuable Plum for dessert, but most esteemed for market and drying or preserving. Fruit long, oval, purple with a thick bloom; flesh firm, sweet and pleasant, separating freely from the stone; moderate growth. A great favorite. A sure market for all you have to sell at very profitable prices.

Lombard-Medium to large roundish, oval, dark red, flesh yellow, juicy and pleasant flavor; hardy popular, nearly always producing a crop, a valuable commercial sort. August.

Monarch-Very large, brilliant; blush purple; flesh, pale golden green; juicy, abundant bearer and begins fruiting young. Free from rot; excellent for market. Sentember.

Reine Claude-Large pale yellow, marked with red, excellent and of fine quality; good bearer; valuable for commercial purposes. Middle of September.

Shipper's Pride-Large and handsome, dark purple quality; fine, juicy and sweet; excellent for canning. September.

Shropshire Damson-Large amber color, juicy and sprightly; most desirable of the Damson class; productive and not liable to rot; good commercial sort. September.

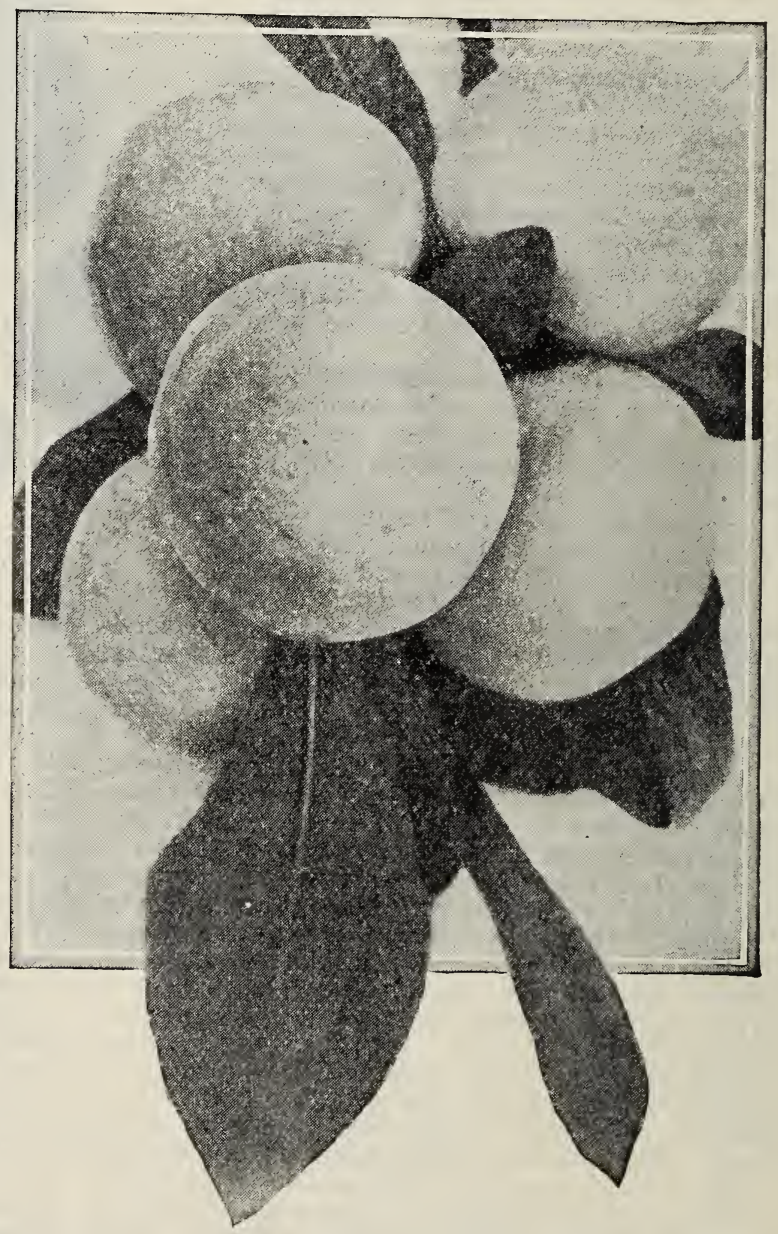

Shropshire Damson

\section{"You'll Never Reg̈ret Planting Kelly Trees"}




\section{Dipect from Grower to Planter}

\section{Japanese Plums}

We have the following list of Japanese plums to offer and we would especially recommend that these be planted at one year, as this reduces considerably the loss from transplanting. 'The roots of plum trees are very tender and are easily injured from exposure to the wind or sun. We also have one year German Prune and Shropshire Damson and York State Prune. Some planters prefer to plant these instead of two year trees. Price is as follows:

$\begin{array}{llllllrr}\text { Largest Size } & 2 \text { Year } & 6 \text { to } 7 \text { Feet } & 3 / 4 \text { and } 4-1 & \text { XXX } & .25 & \$ 2.00 & \text { HUCHDRED } \\ \text { Medium Size } & 2 \text { Year } & 5 \text { to } 6 \text { Feet } & 5 / 8 \text { to } 3 / 4 & X X & .20 & 1.75 & 14.00 \\ \text { Smaller Size } & 2 \text { Year } & 4 \text { to } 5 \text { Feet } & 1 / 2 \text { to } 5 / 8 & X & .15 & 1.25 & 9.00 \\ \text { Largest Size } & 1 \text { Year } & 31 / 2 \text { to } 6 \text { Feet } & & \text { XXX } & .20 & 1.75 & 14.00\end{array}$

Abundance-Fruit large, showy, beautiful. Amber, turning to a rich, bright cherry color, with a decided white bloom, and highly perfumed. Flesh light yellow, exceedingly juicy and tender, of a delicious sweetness impossible to describe. Stone small and parts readily from flesh. For canning it is of greatest excellence. Its season is very early, ripening in advance of other plums, thus adding to its special value.

Burbank-When properly thinned, the fruit is very large, nearly round and bright, deep red; flesh a deep yellow, very sweet, meaty and quite firm, keeping and shipping finely. Tree hardy and vigorous, but sprawling in growth; needs close pruning; enormously productive. Burbank orchards have been very profitable up to date.

Climax-Very large; deep, rich red; fine flavor; one of the earliest to ripen. Mr. Burbank regards this as one of his most valuable productions.

Red June-The best Japan plum, ripening before Abundance. Medium to large; deep vermilion-red, with handsome bloom; flesh light lemon-yellow, firm; moderately juicy; fine quality. Tree upright, spreading, vigorous and hardy ; productive.

Satsuma-Large, globular, with sharp point. Color purple and red with bloom; flesh firm, juicy, dark red or blood color, fine quality; pit very small.

Wickson-A sturdy, upright grower; fruit remarkably handsome, deep maroon-red, covered with white bloom; stone small; flesh fine texture, firm, sugary and delicious; excellent keeper and shipper.

October Purple-Originated by Burbank, who regarded it as one of the best introduced. Fruits on the old wood and frequently measures seven inches in circumference. Tree a strong erect grower, forming a shapely head.

Shiro-Medium size, yellow, and very sweet. The best quality of any of the Japan Plums. We have fruited it in Nursery rows and can recommend it highly for garden planting. Sept.

Sultan-A large handsome Plum of purplishcrimson color; excellent for cooking and preserving. Keeps long and ships well.

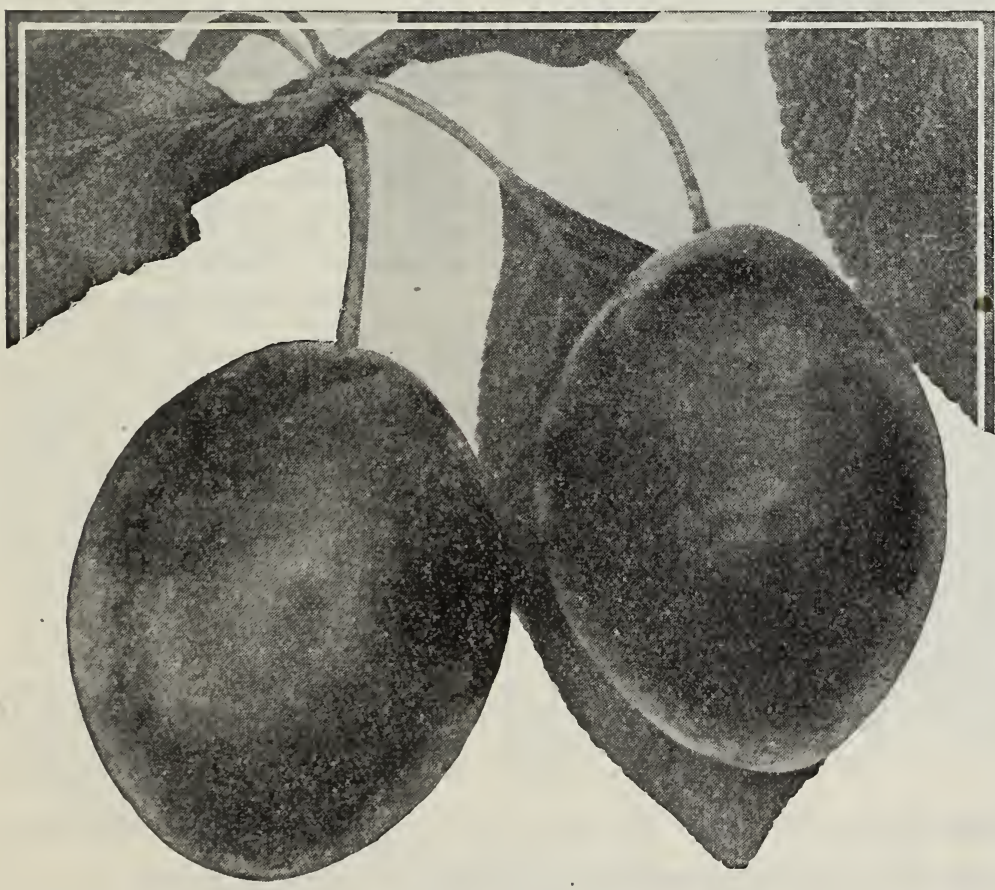

German Prune
Kelly Bros. Plum Trees both European and Japan are budded on Imported French Myrobolan Plum seedlings. This insures a strong healthy growth for the tree. Thus with the plum root system it is much longer lived and less apt to be injured by the severe winter. You cannot compare these trees with Plums offered that are budded on Peach roots. These do not make as healthy a growth and the root system is not hardy enough to withstand the winter weather. Our trees are the very best that can be grown, and you make no mistake in planting Plum trees grown by us.

Putney, Vt., Apr. 21, 1913

Dear Sirs :-The nursery stock which I bought of you arrived in good condition and I am much pleased with it.

Yours very truly, Geo. H. Gassett. 


\section{Quince Trees}

Its pre-eminence as a fruit for jellies and preserves makes the quince a profitable tree for the fruit grower as markets in most localities are undcrsupplicd. Like cherry trees, quince trees will not thrive in wet land. A rich, moist but well-drained soil has been found to give the best results. Quince trees may be planted as closely as 8 to 10 feet apart because of their dwarfish characteristics. It must be controlled, however, or it will develop into a bush. iil suckers and water spouts should be pinched off and the tops of the trees kept open to admit air and sunshine. We recommend the following varieties:

\section{Wholesale Prices of all Varieties of Quince Trees}

\begin{tabular}{|c|c|c|c|c|c|c|c|}
\hline $\begin{array}{l}\text { Largest Size } \\
\text { Medium Size } \\
\text { Smaller Size } \\
\text { Largest Size }\end{array}$ & $\begin{array}{l}2 \text { Year } \\
2 \text { Year } \\
2 \text { Year } \\
1 \text { Year }\end{array}$ & $\begin{array}{l}4 \text { to } 5 \text { Feet } \\
3 \text { to } 4 \text { Feet } \\
2 \text { to } 3 \text { Feet } \\
3 \text { Feet } \& U \text { Up }\end{array}$ & $\begin{array}{l}\frac{9}{16} \text { and up } \\
\frac{7}{\frac{1}{6} 6} \text { to } \frac{9}{16} \\
\frac{5}{16} \text { to } \frac{7}{16}\end{array}$ & $\begin{array}{l}\text { XXX } \\
\text { XX } \\
\text { X } \\
\text { XXX }\end{array}$ & $\begin{array}{l}\text { EACH } \\
.23 \\
.18 \\
.14 \\
.18\end{array}$ & $\begin{array}{c}\text { TEN } \\
\$ 2.00 \\
1.75 \\
1.25 \\
1.75\end{array}$ & $\begin{array}{r}\text { HUNDRED } \\
\$ 17.00 \\
14.00 \\
11.00 \\
14.00\end{array}$ \\
\hline
\end{tabular}

Champion-Fruit very large,

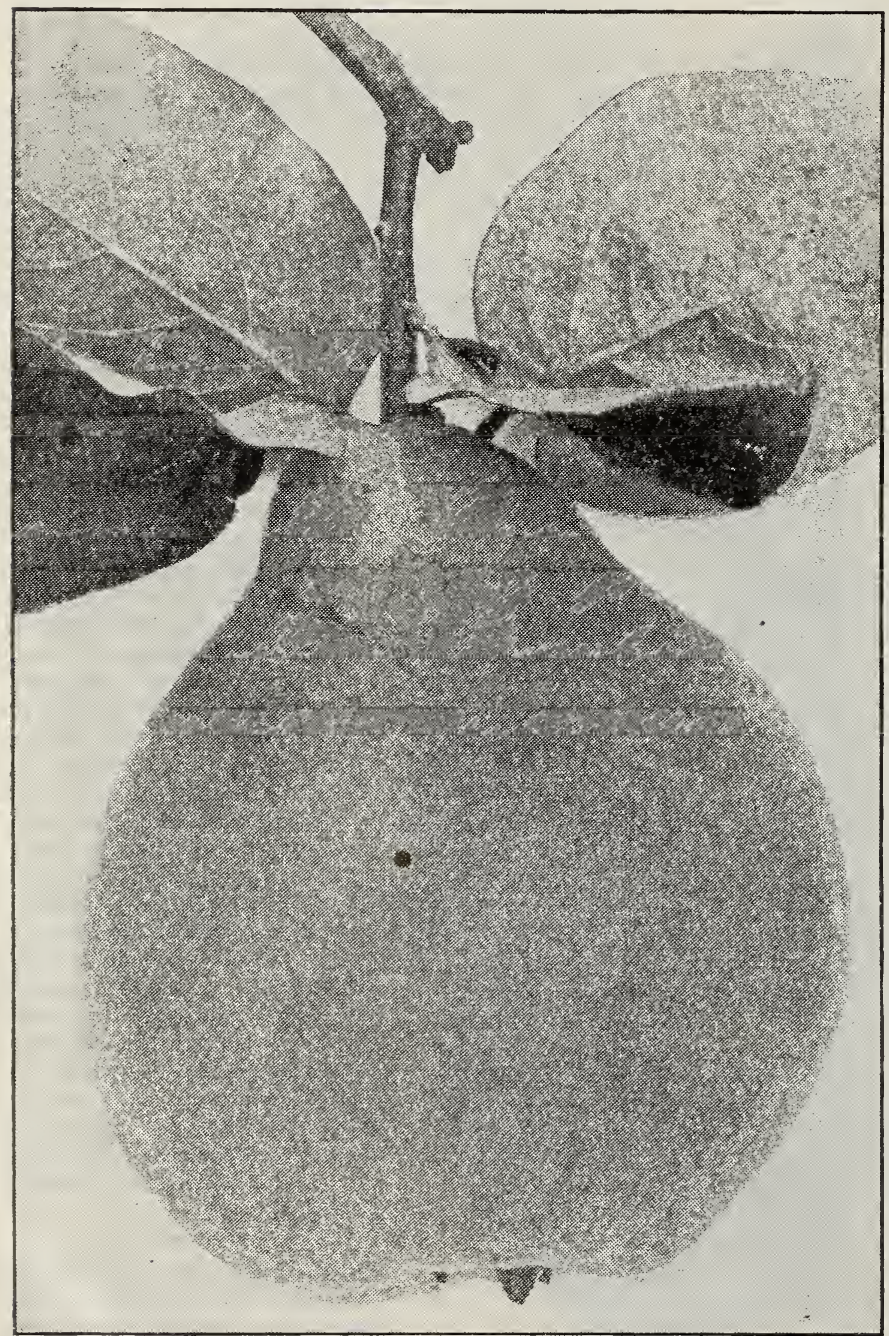

Orange Quince fair and handsome. Tree very handsome, surpassing other varieties in this respect, bears abundantly while young; flesh cooks as tender as an apple and without hard spots and cores; flavor delicate, imparting an exquisite quince taste and odor to any fruit with which it is cooked. One of the most valuable.

Orange-Popular, extensively cultivated, reliable and satisfactory. The name was given in an attempt to do justice to its most delicious flavor. Roundish, bright golden yellow, very large, fine grained, fine quality. Best for cooking. Firm, will stand handling and shipping.

Rea's Mammoth - Large, rich golden yellow; flesh cooks as tender as the apple and without hard spots or cores, flavor delicate, imparting an exquisite quince taste and odor to any fruit with which it is cooled. Sure to ripen even in northern latitude. Very hardy and productive. We regard it the best of all quinces. October.

South Framingham, Mass. June 11, 1913

Kelly Bros., Dansville, N. Y.

Gentlemen :-The trees arrived in fine condition and I was much pleased with the stock. It was excellent, although my order was sent to you late. If I plant in the fall or spring, or if there is anyone I can recommend your trees to, I certainly shall do so. At present I have about 4,000 trees-all kinds - which have come from several nurseries all over the country. The stock you sent me is certainly the best I have had, and the price is reasonable. Thanking you, I remain, Respectifully yours, Robert Hessel.

SEE OUR SPECIAL COLLECTIONS ON LAST PAGE CUT OUT THE MIDDLEMEN IN BUYING NURSERY STOCK. SAVE THE BİG 


\section{Wayne County Orange Quince}

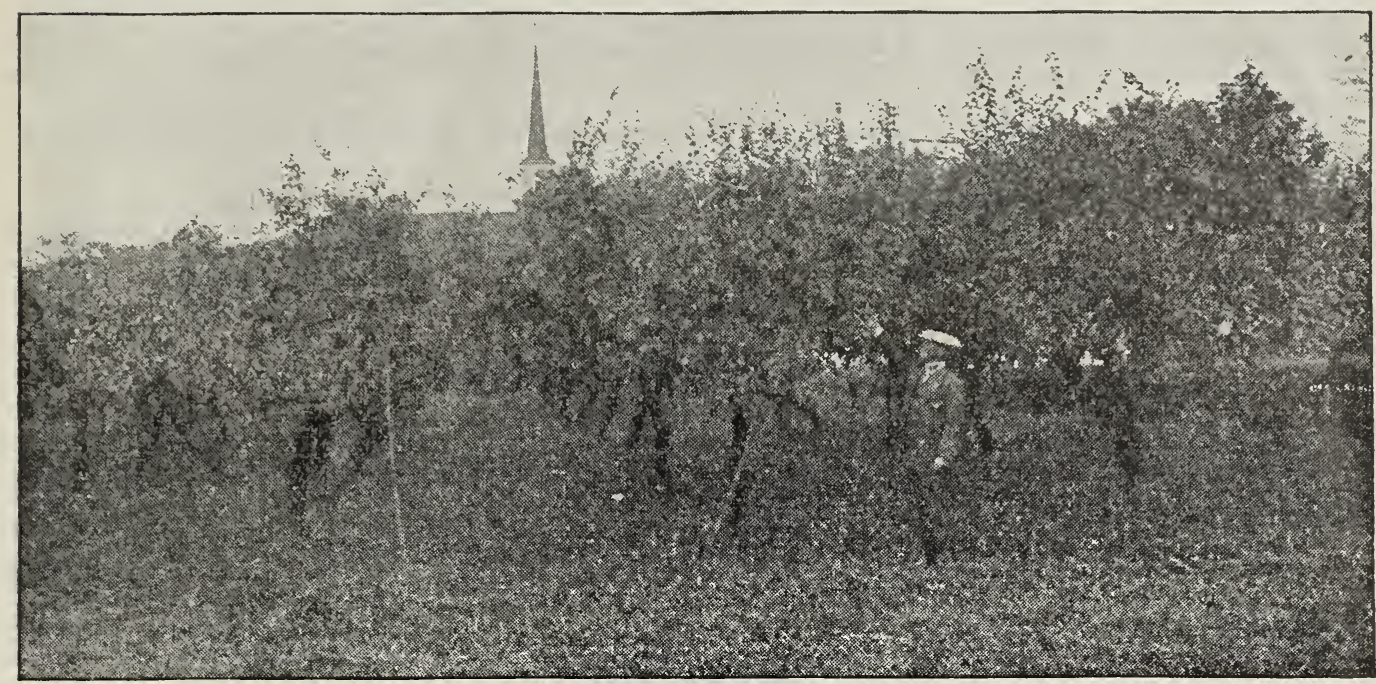

Bearing Orchard of Wayne County Orange Quince on Farm of Mr. Fred Grover, Pultneyville. Wayne Co., N. Y., from which we secure our scions for propagating the Wayne Co. Orange Quince. Mr. James Kelly, Senior Member of our Firm, in the foreground.

A few years ago it came to our attention that the Orange Quince, as generally grown by nurserymen, was not the very best strain of Orange Quince; in fact, it was inferior in many ways to what it should be with reference to flavor, productiveness and size. We at once began to look around to locate some good strain of the real old-fashioned Orange Quince. We had heard of the Orange Quince orchard of Mr. Fred Grover, Pultneyville, Wayne Co., N. Y. (near Williamson), which is located in the heart of one of the greatest fruit belts in the United States. After thorough personal investigation, covering a period of three successive years, each of which saw enormous crops of this luscious golden yellow fruit, we decided we had found the very best Quince. Mr. Grover told us that he had lived on this same farm for over thirty years, and that every year, without exception, this orchard had yielded an enormous crop. In fact it is the most productive of all Quinces.

We then made arrangements with Mr. Grover to secure scions from this orchard. These scions were taken from this orchard by us personally," and we now offer Quince trees propagated in our nurseries from this magnificent strain. The Wayne County Orange Quince is ${ }^{1}$ very large, finegrained, almost round in shape, and of bright golden yellow color. It is from a third to one-half larger than any other Quince we have ever seen. Being very firm it will stand handling and shipping. It is of such delicious flavor that we could not attempt to do justice to its high quality by a mere catalog description. Ripens from September first to fifteenth. As the size, appearance and quality is so much better than that of the ordinary Quinces, Mr. Grover has always had a great demand for his crop, and has always sold his Quinces at a figure far higher than the ruling market price. The tree itself is very thrifty and bears at an early age. Mrs. Grover says she remembers the trees bearing when they were very small; in fact, this variety has fruited in our nurseries at one and two years old. With all sincerity we can recommend this variety for commercial purposes, or for home use. You will make no mistake in planting this most productive, highest quality Quince. Be sure to get the genuine Wayne County Orange Quince direct from Kelly Bros., the introducers. Each tree has attached our Trade Mark label. On one side of the label is printed: "Wayne County Orange Quince;" on the reverse side, "Kelly Bros., Dansville, N. Y."

\section{Wholesale Prices of Wayne Co. Orange Quince}

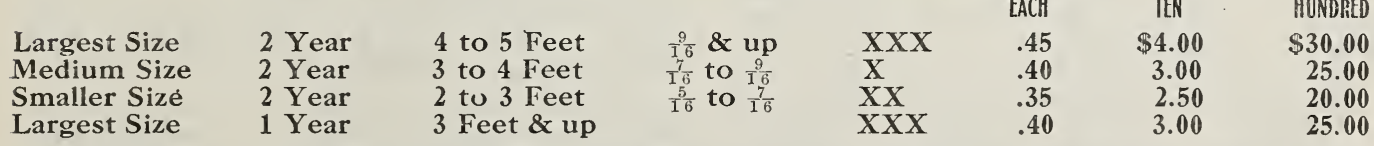

\footnotetext{
蕰 OUR NURSERIES ABSOLUTELY FREE FROM SAN JOSE SCALE

It is an established fact that San Jose Scale has never been found in our nurseries. We have here three resident 4 New York State Inspectors who look after our stock from seedling to freight car, and not once, has this worst of illsect pests made its appearance in our nurseries. Wve welcome the visits of the inspectors, because we inow this help if to keep our stock free from disease. Ours is the only nursery center of any importance in the United States that is absolutely free from San Jose Scale. 


\section{Dwarf Pear Trees}

The cultivation of Dwarf Pears is very profitable. The trees are low-headed and the fruit is easily handled and comes into bearing much earlier than the standard. Pears are dwarfed by budding on Quince stocks and the trees should be planted deep enough to cover the union of pear and quince. All varieties of Pears do not give good results as dwarts. We recommend the following varieties, especially the Duchess, to be good bearers and to give the best satisfaction as dwarfs:

Bartlett, Kieffer, Clapp's Favorite, Beurre d'Anjou, Duchess d'Angouleme, Wilder Early and Seckel. (For description of each, see Standard Pears.)

Wholesale Prices of all Varieties of Dwarf Pear Trees

$\begin{array}{llllllrr} & & & & \text { EACH } & \text { IEN } & \text { HUNDREE } \\ \text { Largest Size } & 2 \text { Year } & 4 \text { to } 5 \text { feet } & 5 / 8 \text { and up } & \mathbf{X X X} & .18 & \$ 1.65 & \$ 14.00 \\ \text { Medium Size } & 2 \text { Year } & 3 \text { to } 4 \text { fest } & 1 / 2 \text { to } 5 / 8 & \mathbf{X X} & .15 & 1.15 & 11.00\end{array}$

\section{Dwanf Apple Trees}

Dwarf Apples are like Dwarf Fears in that they come into bearing early. We offer the following varieties budded on the best imported Paradise and Poucin stocks :

Alexander, King, Winter Banana, Northern Spy, McIntosh, Baldwin, Wealthy, Duchess, Bismarck, Yelow Transparent.

\section{Prices of ali Varieties of Dwarf Apple Trees}

$\begin{array}{lllll} & & \text { EACH } & \text { IEN } & \text { HUNDRED } \\ \text { Largest Size } & 3 \% 2 \text { to } 5 \text { feet } & .35 & \$ 3.00 & \$ 25.00\end{array}$

\section{Apricots}

Much like the peach in flavor, the apricot finds a ready and profitable market as it ripens a month earlier than that fruit. It is as hardy as the peach and will thrive in the same kind of soil. For canning and drying purposes the apricot is used extensively, and in fact, has no superior for the latter purposes. We grow the following stock varieties which we can furnish in one year old.

\section{Prices of Apricot Trees}

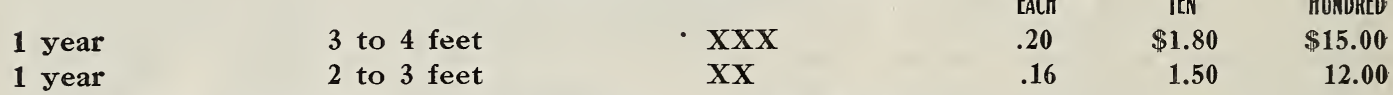

Alexis-Very hardy; an abundant bearer; yellow, with red cheek; large; slightly acid, rich and luscious.

Budd-Medium to large; light orange with blush on sunny side; flesh sweet, juicy with flavor of the peach; hardy and productive.

Harris-A hardy English sort. Medium size; oblong orange; good quality; very early. The best variety for Eastern culture.

Alexander-Fruit yellow, flecked with red, very beautiful and delicious. July.

Moorpark-One of the largest, orange with red cheek; firm, juicy, with a rich flavor; very productive. August.

Gibb-Tree hardy, grows symmetrical, productive. Fruit medium yellowish, sub-acid, juicy and rich. The best early variety ripening soon after strawberries.

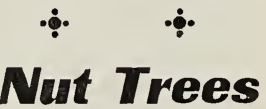

The necessity for the importation of large quantities of nuts each year has awakened American agriculturists to the possibilities in producing nuts. Oftentimes the trees will thrive on soil not adapted to profitable fruit growing.

American Sweet Chestnut-This is the well-known native variety with which nearly everyone is familiar. It is a stately tree, attaining great height when mature. It is beautifully symmetricel and when in blossom is as handsome as a tree can be. It bears a nut of good quality and seldom fails to produce a good crop. Aside from their crop value, all the Chestnuts are specially desirable for shade purposes and for ornamental planting. Trees 4 to $5 \mathrm{ft}$. in height, 35c each; $\$ 3.00$ per 10 .

Black Walnut-This specie is a common and

stately forest tree in the middle and western states; grows from forty to sixty feet high; has an open, spreading head and is rapid in growth; produces large crops of nuts with rough hard shell containing rich, oily kernels of fine flavor. Trees 5 to $6 \mathrm{ft}$., $50 \mathrm{c}$ each; 4 to 5 ft., $35 \mathrm{c} \mathrm{each;} \$ 3.00$ per 10 .

English Walnut-A fine, lofty-growing tree, with handsome, spreading head; produces large crops of thin-shelled, delicious nuts which are always in demand at good prices. Trees 3 to $4 \mathrm{ft.}, 50 \mathrm{c}$ each; 10 for $\$ 4.00$. 


\section{Special Bargains in Fruit Trees}

Many planters prefer to plant the smaller size trees as it reduces the cost of investment. In all cases they report success in planting this grade as the fibers of the roots are small and readily adhere to the ground and make a rapid and very satisfactory growth the first year. A few buyers of fruit trees have an idea that the the smaller size trees are poor trees and are not fit to plant. This is a mistake as each one of our smaller size trees is a good, clean, straight healthy little tree and is first class in every respect according to grade. These small trees are well rooted and mature, and we recommend them most highly to the planter. We have a good stock of Apple, Peach, Pear, Cherry and Plum and offer them at these special low prices:

\section{Apples}

Prices of all Varieties of Apple Trees

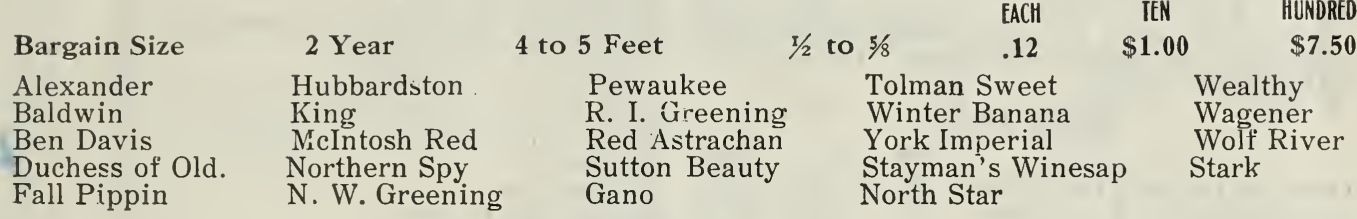

\section{Peaches}

Prices of all Varieties of Peach Trees

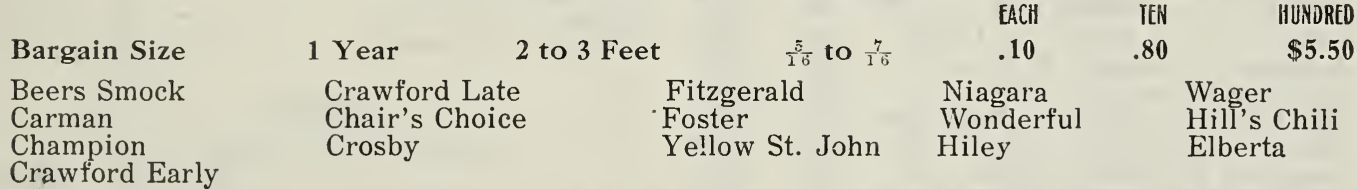

\section{Cherries}

\section{Prices of all Varieties of Cherry Trees}

\section{Bargain Size \\ Bargain Size}

Dyehouse

Early Richmond

English Morello

May Duke

Sour Cherry 2 Year
Sweet Cherry 2 Year
Montmorency
Ostheime
Olivet
Wragg

Montmorency

Olivet

Wragg

4 to 5 Feet $\quad 1 / 2$ to $5 / 8$
4 to 5 Feet $1 / 2$ to $5 / 8$
Bing
Black Tartarian
Gov. Wood
Lambert

Pears

\section{Prices of all Varieties of Pear Trees}

\begin{tabular}{|c|c|c|c|c|c|}
\hline 2 Year & 4 to 5 Feet & $1 / 2$ to $5 / 8$ & $\begin{array}{l}\text { EACH } \\
.15\end{array}$ & $\begin{array}{c}\text { IEN } \\
\$ 1.25\end{array}$ & $\begin{array}{l}\text { LiUNDRED } \\
\$ 11.00\end{array}$ \\
\hline & $\begin{array}{l}\text { s Favorite } \\
\text { sS }\end{array}$ & $\begin{array}{l}\text { Flem } \\
\text { Kieff }\end{array}$ & & & $\begin{array}{l}\text { Ee } \\
\text { Early }\end{array}$ \\
\hline
\end{tabular}

\section{Plums}

\section{Prices of all Varieties of Plum Trees}

\section{[r.CH}

.15
.20

IEN

HUNDRED

$\$ 1.35 \quad \$ 12.00$

$\begin{array}{ll}1.75 & 16.00\end{array}$

Napoleon

Schmidt's Big.

Windsor

Yellow Spanish
Bargain Size

Beurre d' Anjou Bartlett
Bargain Size

Abundance

Burbank

Bradshaw

Climax

$$
2 \text { Year }
$$

German Prune

Fellemburg

Imperial Gage Lombard

$8 \%$ Discount or all Cash Orders amounting to $\$ 4.00$ and up received on or before October 15 th. After that date $3 \%$ Discount un Cash Orders of $\$ 4.00$ and up. 


\section{Ornamental Department}

Well-kept grounds, which necessarily include fine shade trees and ornamental and flowering shrubs, are naturally a source of great pleasure to a property owner. They also greatly enhance the value of property. A relatively small amount invested in ornamentals will bring a big return should you wish to dispose of your property. Nor does it require a big outlay of money to make your property beautiful by such ornamentation. The trees and shrubs of course should not be planted haphazardly. If you do not know just how to go about the matter you can easily obtain competent advice. We take the same care with our ornamental stock that we do with our fruit stock. That means that it is the best.

\section{Evergreens}

AACH

Irish Juniper 2 to $3 \mathrm{ft}$.

Colorado Blue Spruce 3 to $4 \mathrm{ft}$.

Norway Spruce 2 to $3 \mathrm{ft}$.

Balsam Fir 18 to 24 in.

NOTE-We advise the shipping of all evergreen roots balled with earth and tied with burlap. The extra cost for this will be $10 \mathrm{c}$ each.

\section{Shade Trees}

$\begin{array}{llll}\text { Carolina Poplar } 10 \text { to } 12 \text { feet } & .20 & \$ 1.50 & \$ 12.00\end{array}$ Carolina Poplar 8 to 10 feet $\quad .15 \quad 1.30 \quad 10.00$

$\begin{array}{llll}\text { Carolina Poplar } 6 \text { to } 8 \text { feet } & .10 & 80 & 7.50\end{array}$

American Elm 8 to 10 feet

Norway Maple 8 to 10 feet

Purple-Leaved Beech 3 to 4 feet

American Chestnut 6 to 8 feet

Catalpa Speciosa 6 to 8 feet

Am. Linden (Basswood) 6 to 8 feet .50

Catalpa Bungeii 6 to 8 feet

Lombardy Poplar 6 to 8 feet

Cut Leaved Weeping Birch 5 to $6 \mathrm{ft}$. .75

Tea's Weeping Mulberry 4 to 5 feet 1.00

\section{Climbing Vines}

Ampelopsis Veitchii

Chinese Matrimony Vine

Clematis Henryii

Clematis Jackmanni

Wisteria (Chinese Purple)

Wisteria (Chinese White)

Birthwort (Dutchman's Pipe)

Honeysuckle (Hall's Japan)

\section{Hedges}

California Privet 18 to 24 in $45 \% 3.00 \quad \$ 25.00$

California Privet 24 to 30 in. $.65 \quad 4.00 \quad 35.00$

$\$ 1.80$

4.00

18.00

3.00

2.00

4.50

4.50

4.50

4.50

4.50

7.00

2.50

7.00

9.00

\section{Hardy Flowering Shrubs}

Lilac (White)

Hydrangea (P. G.)

Hydrangea (P. G.) $\quad .25$

Hydrangea (Snowball Everblooming) .35

Hydrangea (Tree Form)

Snowball (Viburnum)

Rose of Sharon (Althea)

Althea (Variegated)

Weigelas

Golden Glow

Spirea Van Houttei

Spirea Callosa Rosea

Spirea Prunifolia

EACH TfN Deutzia (Pride of Rochester)

$\$ 4.50$ Deutzia (Gracilis)

Aureus

Barberry Thumbergii

$\begin{array}{rr}\text { EACH } & \text { IEN } \\ .25 & \$ 2.00 \\ .25 & 2.00 \\ .25 & 2.00 \\ .35 & 3.00 \\ .50 & 4.50 \\ .25 & 2.00 \\ .25 & 2.00 \\ .35 & 3.00 \\ .20 & 1.75 \\ .10 & .90 \\ .25 & 2.00 \\ .25 & 2.00 \\ .30 & 2.50 \\ .25 & 2.00 \\ .35 & 3.00 \\ .25 & 2.00 \\ .20 & 1.90\end{array}$

\section{Roses}

Prices on All Varieties

$\begin{array}{llcr} & \text { EACH } & \text { TEN } & \text { HUNDRED } \\ \text { Strong } 2 \text { yr. Bushes : } & .20 & \$ 1.80 & \$ 16.00\end{array}$

VARIETIES :- Alfred Colomb (Crimson), American Beauty (Deep Rose), Baron des Bonstetten (Maroon), Clio (Flesh Color), Coquette EACH IEN des Alps (White), Crimson Baby Rambler, $.35 \$ 3.00$ Dorothy Perkins (White), Frau Karl Druschki $.35 \quad 3.00$ (White), Magna Charta (Pink), Margaret Dick.353 .00 son (White), Mrs. John Laing (Pink), Marshall 353.00 P. Wilder (Carmine), Crimson Rambler, Co2.00 quette des Blanches (White), Gen. Jacqueminot 2.00 (Crimson), Earl of Dufferin (Crimson), La 3.00 France (Pink), Paul Neyron (Red), Killarney 2.00 (Pink and White), Ulrich Brunner (Red), Persian Yellow.

MOSS ROSES:-Prince Camile de Rohan (Crimson), Mad. Plantier (White), Prairie Queen (Red), Anne de Diesbach (Carmine), Baltimore Belle (White), Hugh Dickson (Crimson.)

\section{Strawberries}

\section{Wholesale Prices on All Varieties}

$\begin{array}{ccr}\text { IWENTY-FIVE } & \text { HUNDRED } & \text { IHOUSAND } \\ .30 & .60 & \$ 4.50\end{array}$

Varieties:-Brandywine, Corsican, Jessie, Marshall, Senator Dunlap, McKinley, Sample, Wilson.

\section{Garden Roots}

\section{Asparagus}

$\begin{array}{llr} & \text { IEN } & \text { HUNDRED } \\ \text { Cionovers Colossal } & .15 & \$ 1.00 \\ \text { Palmetto } & .15 & 1.00\end{array}$

\section{Rhubarb (Pie Plant)}

\begin{tabular}{|c|c|c|c|c|}
\hline THOUSAND & & $\mathrm{EACH}$ & IEN & HUNDRED \\
\hline$\$ 6.00$ & Linneaus & .10 & .60 & $\$ 4.00$ \\
\hline 6.00 & Early Scarlet & .10 & .60 & 4.00 \\
\hline
\end{tabular}




\section{Small Fruits}

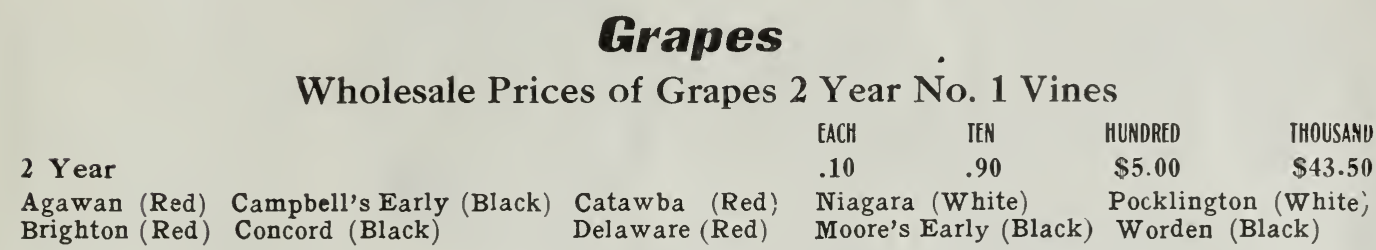

\section{Blackberries}

Wholesale Prices of Blackberries

Strong well rooted plants

Blowers

Eldorado
EACH IEN

$.08 \quad .50$

Erie

Mersereau $\begin{array}{rr}\text { HUNDRED } & \text { THOUSAND } \\ \$ 2.00 & \$ 17.50\end{array}$

Snyder

Rathbun

\section{Raspberries}

Wholesale Prices of 2 Year, Strong, Healthy Plants

\begin{tabular}{|c|c|c|c|c|c|c|c|c|}
\hline & & & & & IEN & TWENTY-FIVE & HUNDRED & THOUSAND \\
\hline Cumberland (Black) & - & & - & - & .35 & .65 & $\$ 1.50$ & $\$ 13.50$ \\
\hline Kansas (Black) & & - & - & - & .35 & .65 & 1.50 & 13.50 \\
\hline Gregg (Black) & - & & - & - & .35 & .65 & 1.50 & 13.50 \\
\hline Ohio (Black) & . & - & - & - & .35 & .65 & 1.50 & 13.50 \\
\hline Diamond (Black) & - & & - & - & .35 & .65 & 1.50 & 13.50 \\
\hline Conrath (Early Black) & & - & - & - & .35 & .65 & $1.5 !)$ & 13.50 \\
\hline Plum Farmer (Black) & - & - & & - & .35 & .65 & 1.50 & 13.50 \\
\hline Columbian (Purple) & - & & - & - & .35 & .65 & 1.50 & 13.50 \\
\hline Cuthbert (Red) & - & - & - & - & .30 & .60 & 1.00 & 9.00 \\
\hline Loudon (Red) & - & & - & - & .50 & .75 & 1.50 & 12.00 \\
\hline Marlboro (Red) & & - & - & - & .35 & .60 & 1.00 & 9.00 \\
\hline Golden Queen (Yellow) & v) & & - & - & .50 & .75 & 1.75 & 13.50 \\
\hline St. Regis Everbearing & (Red) & & - & . & .60 & 1.00 & 2.50 & 22.50 \\
\hline
\end{tabular}

\section{Currants}

Wholesale Prices of all Varieties of Currants

(Except Where Otherwise Noted)

2 Year Strong Bushes

Fay's Prolific (Red)

Red Cross (Red)
Perfection (Red)

\begin{tabular}{lcccr} 
& EACH & IEN & HUNDRED & THOUSAND \\
& .10 & .75 & $\$ 4.50$ & $\$ 40.00$ \\
Wilder (Red) & & & Black Champion (Black) \\
Cherry (Red) & & \multicolumn{3}{c}{ White Grape (White) } \\
EACH .15 & IEN $\$ 1.25$ & & $\$ 10.00$ HUNDRE
\end{tabular}

\section{Gooseberries}

Wholesale Prices for Gooseberries 2 Year Strong Bushes

Chautauqua

EACH

TEN

HUNORED

$.20 \$ 1.65$

Downing

Houghton

Industry

Red Jacket

.12

.15
.20

.15 


\section{Special Bargains in Collections of Fruit Trees for the Garden and Orchard}

\section{Kelly's Collection for the Home No. 1}

$\$ 3.75$ worth of Trees, Special Collection Price $\$ 2.50$

1 Red Astrachan Apple, 1 R. I. Greening Apple, 1 Northern Spy Apple, 1 Baldwin Apple, 1 Ey. Richmond Cherry, 1 Napoleon Cherry, 1 Montmorency Cherry, 2 Elberta Peach, 1 Ey. Crawford Peach, 1 Burbank Plum, 1 Abundance Plum, 1 Lombard Plum Thirteen trees, all the largest size, XXX Grade $\$ 2.50$

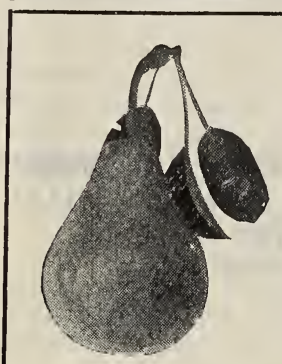

Standard Pear Tree Collection No. 2

1 Flemish Bty. 1 Sheldon, 2 Kieffer, 1 Wilder Early, 1 Beurre'd Anjou, 1 Seckel 1 Bartlett, 1 Clapp's Fav., 1 Duchess 'd Angouleme

10 first class trees. 4 to 5 feet for $\$ 1.50$

Special Collection for the Garden No.3

2 Elberta Peach, 1 Ey. Crawford Peach, 1 Montmorency Cherry, 1 Early Richmond Cherry, 1 Lambert Cherry, 1 Kieffer Pear, 1 Bartlett Pear, 1 Seckel Pear, 1 German Prune, 1 Lombard Plum, 1 Bradshaw Plum.

12 First Class, X Grade Trees, worth $\$ 2.10$ for $\$ 1.50$

\section{Grape Collection No. 4}

3 Concord, 2 Delaware, 2 Campbell's Early, 2 Moore's Early, 2 Niagara, 1 Pocklington 12 good, thrifty Vines, Special price 75 cents

\section{Rose Collection No. 5}

1 Am. Beauty, 1 Crimson Rambler, 1 Karl Druschki, 1 Marshall P. Wilder, 1 Coquette des Alps, 1 Dorothy Perkins.

Six 2 year strong bushes, Special Price $\$ 1.00$

Peach Tree Collection No. 6

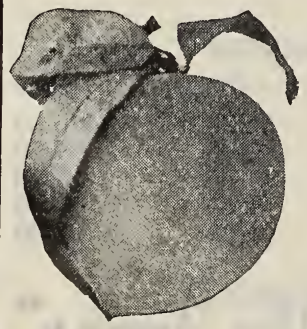

3 Elberta

2 Champion

2 Late Crawforc

1 Carman

2 Early Crawford

10 Peach Trees, 3 to 4 Feet, 85 Cents

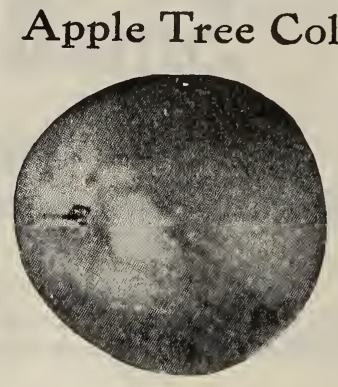

ection No. $z$

1 York Imperial

1 Baldwin

1 Winter Banana

1 Wealthy

1 Northern Spy

1 King

1 Wolf River

1 R. I. Greening

1 Pewaukee

1 Stark

10 Apple Trees, 4 to 5 Feet, $\$ 1.10$

\section{Plum Tree Collection No. 8}

1 German Prune

1 Lombard

1 Abundance

1 Burbank

1 Bradshaw

5 Plum Trees, 4 to 5

Feet 75 Cents

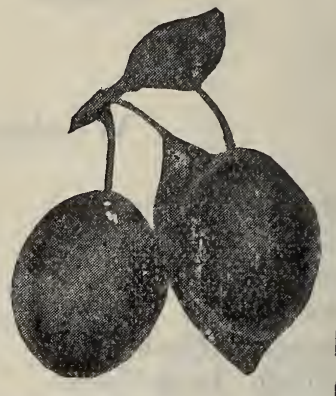

\section{Currant Collection No. 9}

10 strong 2 year bushes for 50 cents

3 Red Cross

3 Wilder (Red)

2 Wnite Grape

2 Black Champion

Special Blackberry Collection No. 10

24 Strong Plants for 80 Cents

6 Eldorado

6 Lawton

6 Snyder

6 Mersereau

All strictly first-class plants 24 in all

Cherry Tree Collection No. 11

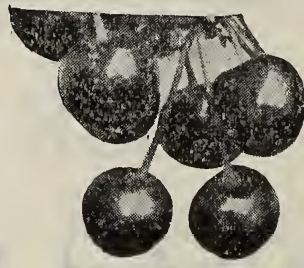

1 May Duke, 1 Olivet, 1 Bing, 1 Early Richmond, 2 Large Montmorency, 1 Lambert, 1 Napoleon

8 first class, $X$ Grade, Cherry trees, Special Price 90 Cents. 


\section{Advice to Planters}

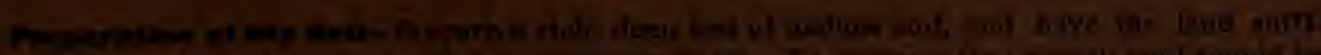

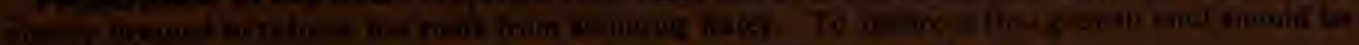

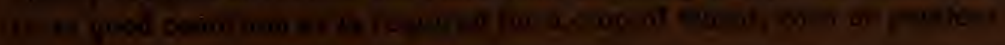

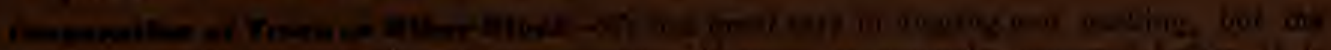
Lat an

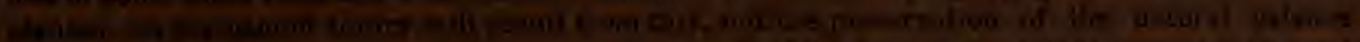
6. a f

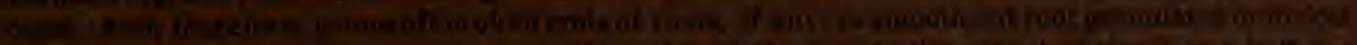

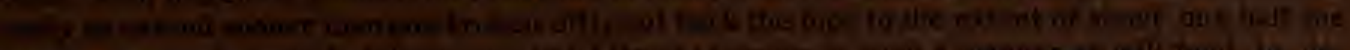

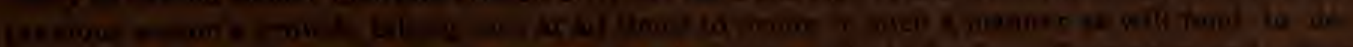

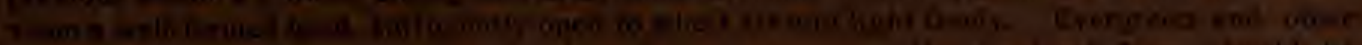

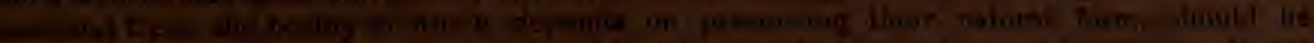

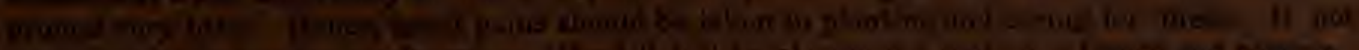

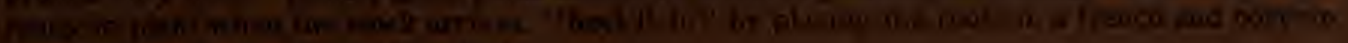

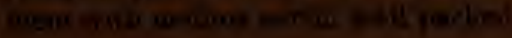

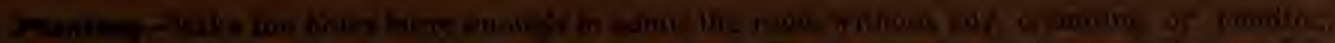

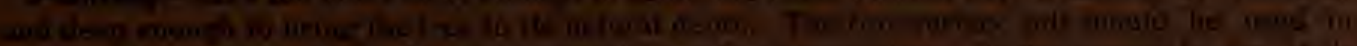

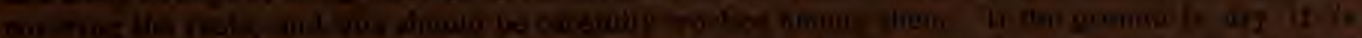

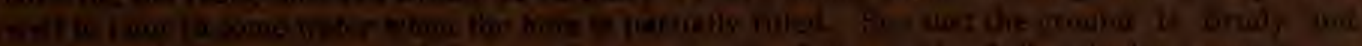

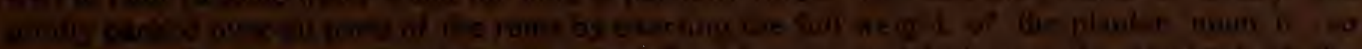

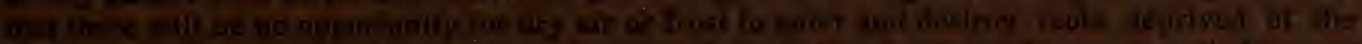

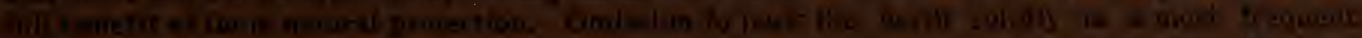

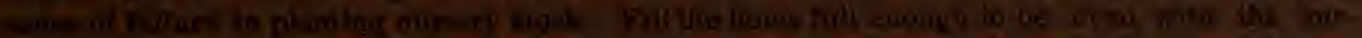

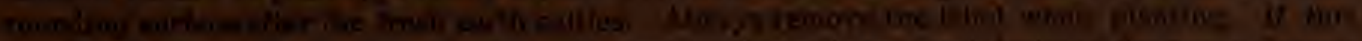

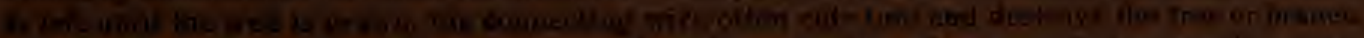
b.

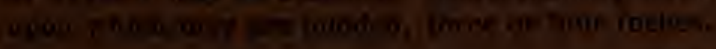

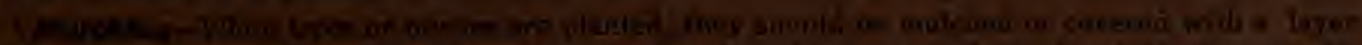

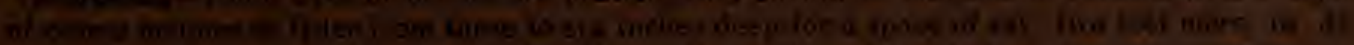

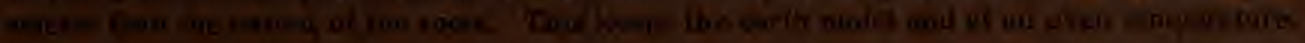

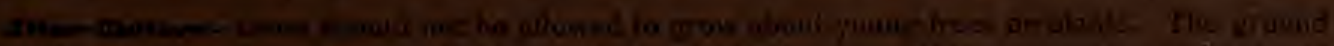

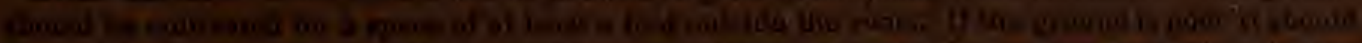

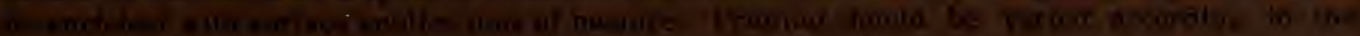

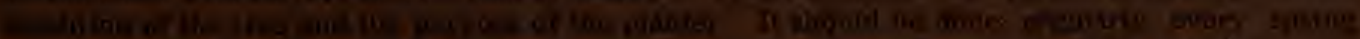

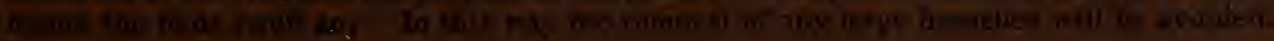

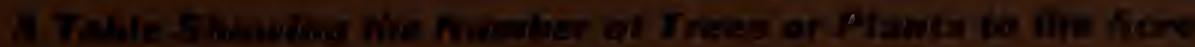

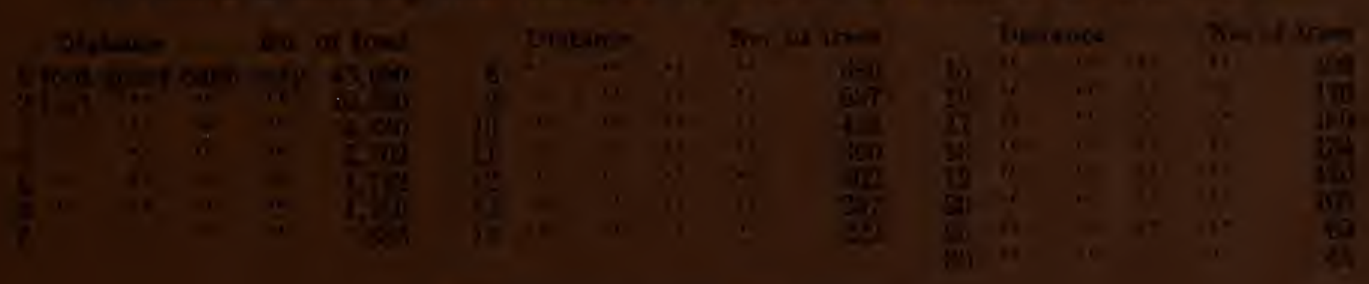

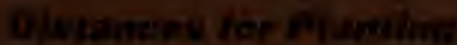

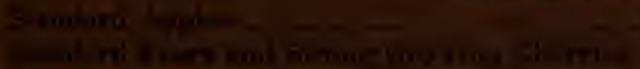

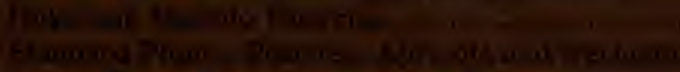

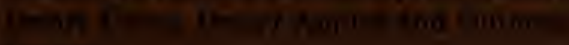

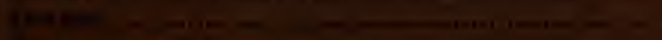

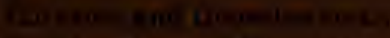

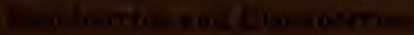

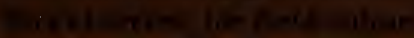

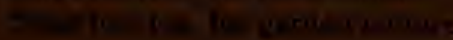

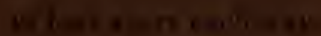
$-$

$18=$

(1) 19

ation $\mathrm{F}$

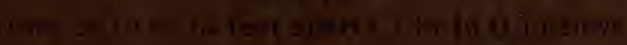

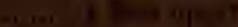

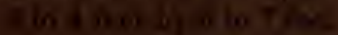

in th $x x_{x}$ thes

nithes ingert

\section{"Xoull Neves Regignel Planting Kelly Trees"}




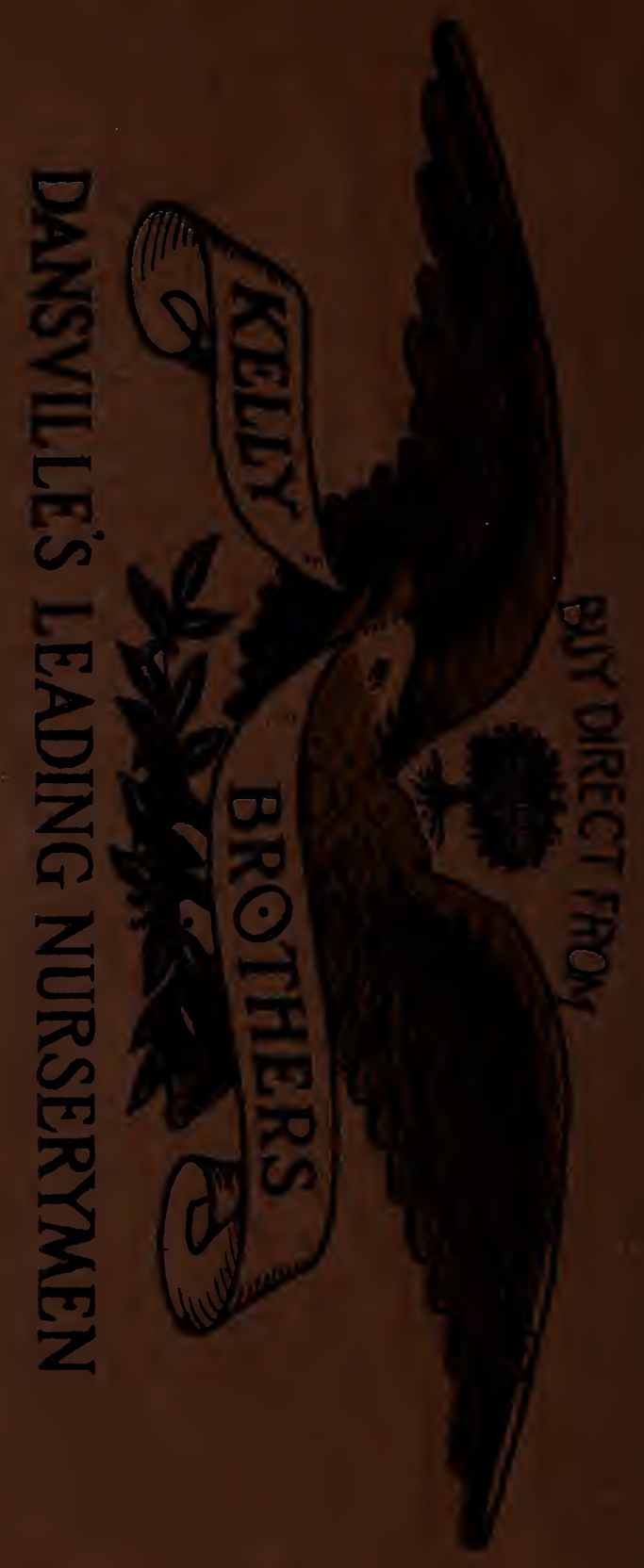

